\title{
STRATEGI PENGEMBANGAN KULINER TRADISIONAL BETAWI DI DKI JAKARTA
}

\author{
Dhian Tyas Untari \\ tyas_un@yahoo.co.id \\ Prodi FIPPS, Universitas Indraprasta PGRI \\ Ricky Avenzora \\ Dudung Darusman \\ Harnios Arief \\ Prodi Manajemen Ekowisata Dan Jasa Lingkungan, IPB \\ Joko Prihatno \\ Kementrian Lingkungan Hidup Dan Kehutanan Indonesia
}

\begin{abstract}
Betawi is a reflection of the acculturation process of several tribes in Indonesia and even some nations in the world. But in fact, the existence of Betawi Culinary Culture is now starting eroded by the concept of modernization. Culinary is one of the cultural products of a society, as well as Betawi Culinary. Where now aday Betawi Culinary is not a superior culinary in Jakarta. Thus it is necessary to made a business revitalization strategy in developing traditional culinary (Betawi) in Jakarta. Thus in general purpose of the research is to build Betawi Culinary development strategy in Jakarta, so the Traditional Betawi Culinari, will clasified on 3 classification; Familiar Culinary, Recall Culinary and Past Known Culinary. Quantitaive Metode used; EFAS/IFAS matrix, Grand Matris and SWOT. Pairwise comparing and eigenfactor score used as a referral to giving equal weight on EFAS/ IFAS matrix. Result of the study show that cross-sectoral coordination, Strengthening the marketing system and increase the economic value of Betawi Culinary are needed to increasing the existence of culinary betawi in global market. The results expected to be reference for any relevant agencies in develomping traditional culinary as a culture product.
\end{abstract}

Key words: Betawi culinary, strategy, Jakarta, pairwise compaling

\begin{abstract}
ABSTRAK
Betawi merupakan hasil akulturasi dari beberapa suku di Indonesia bahkan beberapa bangsa di dunia. Tetapi pada kenyataanya eksistensi Budaya Kuliner Betawi kini mulai tergerus oleh konsep modernisasi. Kuliner merupakan salah satu produk budaya sebuah masyarakat, begitu juga Kuliner Betawi. Dimana dalam perkembangannya Kuliner Betawi bukan lagi menjadi yang kuliner superior di Jakarta. Dengan demikian perlu sebuah usaha revitalisasi strategi dalam mengembangkan kuliner tradisional Betawi di Jakarta. Dengan demikian secara umum tujuan dari penelitian adalah untuk membangun strategi pengembangan Kuliner Betawi di Jakarta guna mengoptimalkan potensi yang dimiliki. Kuliner Betawi diklasifikasikan dalam 3 klasifikasi yaitu; Kuliner Familiar, Kuliner Recalll dan Kuliner Past Known. Penelitian menggunakan metode kualitatif; matrik EFAS/ IFAS, Grand Matrik dan SWOT. Dalam pembobotan matrik EFAS/ IFAS peneliti menggunakan nilai eigenfaktor dan metode pairwise comparing. Hasil penelitian menunjukkan bahwa tiga hal penting yang perlu diperbaiki dalam pengembangan Kuliner Tradisional Betawi adalah, penguatan koordinasi lintas sektoral, penguatan sistem pemasaran dan peningkatan nilai ekonomis dari Kuliner Betawi.
\end{abstract}

Kata kunci : kuliner Betawi, strategi, Jakarta, pairwise compaling 


\section{PENDAHULUAN}

Suku Betawi merupakan suku yang mendiami Kota Jakarta, bahkan sejarah mencatat bahwa Suku Betawi merupakan hasil akulturasi dari beberapa suku di Indonesia bahkan beberapa bangsa di dunia (Untari et al, 2017a). Tetapi pada kenyataannya eksistensi Budaya Kuliner Betawi kini mulai tergerus oleh konsep modernisasi yang merupakan konsekuensi dari berkembangnya Jakarta menjadi Kota Megapolitan, bahkan dikatakan Jakarta adalah salah satu kota cosmopolitan terbesar di Asia Tenggara (Parami, 2006). Dan dalam perkembangannya Kuliner Betawi bukan lagi menjadi yang kuliner superior di Jakarta. Perkembangan Kota memberi pengaruh yang cukup signifikan pada pola hidup masyarakatnya (Pisman et al., 2011). Preferensi masyarakat Jakarta mulai bergeser pada kuliner western, eastern dan fussion (Untari, 2016), sehingga makin menjauhkan kehidupan masyarakat dari nilai-nilai akar budaya yang terrefleksi dari variasi Kuliner Betawi.

Salah satu produk budaya yang sangat erat kaitannya dengan kehidupan manusia adalah kuliner. Kuliner bukan hanya sebagai pemenuh kebutuhan fisiologis manusia, tetapi kuliner juga merupakan representasi sosial budaya dari sebuah masyarakat (Avenzora et al, 2014). Bahkan popularitas dari sektor kuliner dapat terlihat dari pertumbuhan pasar makanan dan tingginya pertumbuhan bisnis restoran pada skala menengah dan besar. Prosek pengembangan bisnis kuliner secara makro dapat dilihat dati kontribusinya yang besar bagi pertumbuhan ekonomi nasional (Ongkorahardjo, 2015; Untari dan Satria, 2014), dimana kontribusi produk makanan, minuman pada penerimaan devisa hingga kuartal III 2014 mencapai USD 1,64 miliar.

Hal yang masih sangat disayangkan bahwa perkembangan sektor kuliner saat ini berbanding terbalik dengan eksistensi Kuliner Tradisional khususnya Kuliner Betawi. Eksistensi Budaya Kuliner Betawi kini mulai tergerus oleh konsep modernisasi yang merupakan konsekuensi dari berkembangnya Jakarta menjadi Kota Megapolitan (Untari et al, 2017b), bahkan di katakan Jakarta adalah salah satu kota cosmopolitan terbesar di Asia Tenggara (Parami, 2006), dan hal ini memberikan pengaruh yang cukup signifikan pada pola hidup masyarakatnya (Pisman et al., 2011). Preferensi masyarakat perkotaan bergeser seiring dengan dinamika moderenisasi yang berlaku secara global ( $\mathrm{O}^{\prime}$ Callaghan et al., 2017), begitu juga terjadi pada masyarakat Jakarta yang modern, dimana preferensi mulai bergeser pada kuliner western, eastern, fussion dan fastfood kini menjadi salah satu pilihan bagi masyarakat perkotaan yang sibuk dengan aktifitasnya Mufidah (2012). Hal ini makin menjauhkan kehidupan masyarakat Jakarta dari nilai nilai akar budaya.

Penetrasi Pasar Kuliner Tradisioanl Betawi pada pasar masyarakat urban di DKI Jakarta memiliki fungsi ganda. Selain mengembalikan eksistensi Budaya Betawi, pengembangan pasar Kuliner Tradisional Betawi akan memberikan nilai lebih bagi UKM pengrajin dan pedagang Kuliner Tradisional Betawi. Oleh sebab itu, perlu sebuah gambaran yang kongriet tentang posisioning pasar Kuliner Tradisional Betawi saat ini. Memahami peta posisioning Kuliner Tradisional Betawi saat ini sangat berpengaruh pada model strategi yang akan dibangun. Berdasarkan latar belakang tersebut, maka penelitian ini bertujuan untuk menyusun rencana strategis pengembangan Kuliner Tradisional Betawi sehingga dapat meningkatkan kemampuan bersaing Kuliner Tradisional Betawi pada pasar global.

\section{TINJAUAN TEORETIS}

\section{Kuliner Dan Kehidupan Masyarakat}

Istilah kuliner dalam kamus besar bahasa Inggris bahwa definisi culinary adalah sebuah yang berhubungan dengan memasak dan dapur dengan demikian secara harfiah kuliner adalah dapur yang biasa digunakan untuk merujuk pada sesuatu yang berhubungan dengan memasak 
atau profesi kuliner. Tetapi istilah lain dikenal dengan nama gastronomi. Andika (2008) dalam Sabudi (2011) menyatakan bahwa istilah kuliner merupakan pengalihan bahasa dari bahasa asing sehingga terjadi kerancuan berpikir kalau yang dimaksud adalah seni mengolah atau menyajikan hidangan yang lezat itu salah, terminologi yang tepat adalah gastronomi. Tetapi terkait pengembangan, pada konsep pemasaran secara umum dan khususnya pada produk makanan pemakaian istilah, label, merek adalah hal yang penting, label yang mudah diingat menentukan keberhasilan sebuah produk dalam memasuki dan menguasai pasar, oleh sebab itu istilah kuliner yang saat ini sudah banyak digunakan akan sangat bermanfaat memperkuat brand recognize dalam konsep pengembangan "makanan" tradisional.

Pembahasan kuliner merupakan suatu hal yang cukup kompleks. Kuliner sangat terkait dengan ilmu lain di luar ilmu perhotelan, dimana pada ilmu perhotelan permasalahan tentang kuliner lebih sering dikaitkan dengan kualitas produk makanan, kualitas layanan dan penyiapan SDM serta hal-hal lain yang menyempitkan pembahasan kuliner hanya pada permasalahan hospitality saja. Sedangkan secara lebih luas kuliner sangat terkait dengan ilmu pangan, ekologi lingkungan, rekayasa teknologi dan seni. Dengan demikian dapat dikatakan kuliner adalah perpaduan berbagai ilmu yang secara holistik saling berhubungan satu dengan yang lainnya.

Kuliner sangat terkait dengan ilmu pangan, dimana makanan yang merupakan bagian dari kuliner merupakan sumber energi bagi manusia. Gizi dan nutrisi merupakan faktor penentu utama kualitas sumber daya manusia (Krisnansari, 2010) sehingga komposisi gizi dan nutrisi dalam makanan merupakan salah satu hal yang penting dalam pengembangan kuliner. Menganalisis gizi dan merekayasa bahan pangan menjadi jawaban dari kerterbatasan sumber pangan yang dialami oleh sebagian besar negara di Dunia. Kuliner merupakan refleksi hubungan manusia dengan lingkungannya. Bahan dasar makanan sangat tergantung pada keadaan lingkungan wilayah tersebut. Tanaman pangan di Indonesia sangat beragam. Hal itu dikarenakan adanya keragaman tipe agroekologi Indonesia yang tercermin oleh beragamnya sifat fisik wilayah, kemiringan, maupun ketinggian tempat dari permukaan laut. Keragaman tersebut menyebabkan terdapat beberapa macam tipe lahan. Indonesia juga mempunyai iklim tropis basah yang dicirikan oleh curah hujan yang tinggi, diikuti oleh keragaman suhu yang ditentukan oleh tinggi tempat dari permukaan laut. Keragaman wilayah, topografi, tanah, ketersediaan air, dan iklim telah membentuk tanaman untuk tumbuh dan beradaptasi pada lokasi yang spesifik (Rais, 2004).

\section{Strategi Pemasaran Sebuah Tantangan Dalam Pengembangan Kuliner}

Menyusun sebuah strategi dalam mengembangkan sebuah produk termasuk produk wisata adalah sebuah hal yang mutlak diperlukan. Menurut Boyd et al. (2000) strategi adalah pola fundamental dari tujuan sekarang dan yang direncanakan, pengerahan sumber daya dan interaksi dari organisasi dengan pasar, pesaing dan faktorfaktor lingkungan lain. Salah satu elemen dari strategi pemasaran adalah bauran pemasaran. Pengembangan strategi pemasaran sangat berkaitan dengan keberlanjutan usaha tersebut dimana melalui perencanaan sebuah strategi yang matang dapat membantu dalam mencapaian tujuan akhir yang ingin dicapai dan fokus pada visi dan prioritas-prioritas yang perlu dikembangkan sebagai respon dari lingkungan yang selalu berubah dan juga melalui perencanaan strategi yang matang dapat memastikan bahwa semua stakeholder yang ikut berperan dalam pengembangan produk dapat bekerja kearah tujuan yang ingin dicapai.

Menyusun sebuah strategis merupakan sebuah kegiatan yang kompleks dan saling terintegrasi satu dengan yang lain, hal ini 
mencangkup kegiatan mengidentifikasi pilihan-pilihan yang menjadi prioritas, menformulasi lalu mengimplementasikan strategi serta membuat sebuah evaluasi sebagai tolak ukur keberhasilan startegi tersebut. Strategi dibutuhkan dalam mengembangkan sebuah produk dan dalam pengembangan produk wisata, keputusan strategis menyangkut tiga parameter utama yaitu dimensi who, yaitu siapa yang menjadi target pelanggan, dimensi what yaitu produk atau jasa apa yang akan ditawarkan, lalu dimensi yang ketiga adalah how yaitu aktivitas yang akan dilakukan untuk mewujudkannya (Tjiptono, 2008). Kastaman (2003: 2) dalam penelitiannya mengungkapkan bahwa strategi penting untuk mendapatkan kesuksesan dalam bidang pemasaran produk meliputi keunggulan dalam biaya atau ongkos (cost leadership), keunggulan karena adanya ciri pembeda atau keunikan dari produk yang dibuat (diferensiasi) dan keunggulan karena memfokuskan pada target atau segmen pasar tertentu.

\section{METODE PENELITIAN}

Penelitian akan menghasilkan tiga model strategi pengembangan untuk klasifikasi kuliner yaitu kuliner Betawi familiar, recall dan past known, hal ini bertujuan untuk menyusun alternatif strategi dari masingmasing kategori agar semua kategori makanan dapat mencapai titik maksimal dan bertahan pada posisi maksimalnya. Metode yang digunakan dalam penyusunan alternatif strategi adalah metode kualitatif dimana terdapat tiga metode yang digunakan yaitu metode input, pencocokan dan penyususnan strategi (David, 2005). Metode input, peneliti akan mengunakan matrik IFAS/EFAS dengan menyusun key factors sebagai faktor yang mempengaruhi pengembangan kuliner secara internal dan eksternal; metode penyesuaian dengan menggunakan matrik Grand Strategi dan SWOT. Pada tahap pengembangan model akan dilakukan validasi dan pengujian model strategi pengembangan kuliner Betawi dengan langkah-langkah: 1) penyem- purnaan draf strategi; 2) uji pakar dengan melibatkan pakar pemasaran; 3) perbaikan model berdasarkan masukan pakar; 4) validasi dan uji lapangan melalui focus group discussion (FGD); dan 5) finalisasi model pemasaran. Produk akhir dari penelitian ini adalah berupa model strategi pengembangan ekowisata kuliner Betawi di DKI Jakarta.

\section{ANALISIS DAN PEMBAHASAN}

Makanan Sebagai Identitas Budaya Betawi

Dalam kurun waktu 10 tahun belakangan, kuliner dan pelestarian budaya menjadi pembahasan hangat pada masyarakat. Hal ini cukup beralasan mengingat makan memiliki fungsi yang cukup kompleks, selain pemenuh kebutuhan fisiologis, makanan juga memiliki hubungan dengan nilai sejarah dan politik ekonomi (Maberly dan Reid, 2014), selain itu makanan dan penyajiannya juga mencerminkan kebiasaan dan prilaku sebuah masyarakat (Parys, 2013). Kuliner di setiap wilayah sangat beragam, hal ini banyak dipengaruhi oleh keadaan fisik lahan (Saputra et al., 2015), morpologi tanah (Jones et al., 2015) dan iklim yang ada di wilayah tersebut (Perry et al., 2004; Simelton et al., 2012).

Kelestarian budaya dan kesenian memang merupakan momok bagi hampir semua kota besar di penjuru dunia, tak terkecuali di Jakarta. Hal ini juga terjadi pada masyarakat Suku Betawi sebagai penduduk asli Jakarta, dimana masyarakat Betawi saat ini mulai tersingkirkan. Mereka keluar dari Jakarta dan pindah ke wilayahwilayah yang ada di provinsi Jawa Barat dan provinsi Banten. Budaya Betawi pun tersingkirkan oleh budaya lain baik dari Indonesia maupun budaya barat.

Kuliner merupakan salah satu produk budaya, oleh sebab itu kuliner menjadi sangat penting sebagai Budaya Betawi karena kuliner menjadi refleksi dari hubungan Suku Betawi dengan lingkungannya. Sejarah panjang perkembangan Suku Betawi di Jakarta memperlihatkan bagaimana Masyarakat Betawi beralkuturasi dengan budaya daerah lain di Nusantara bahkan 
budaya asing yang dibawa oleh penjajah, pedagang dan penyebaran agama (Untari et al, 2017a).

Hasil penelitian telah menginventarisasi 150 jenis kuliner yang dapat diklasifikasikan menjadi beberapa kelompok yaitu klasifikasi umum, fungsi sosial, nilai sejarah, nilai pembaharuan, modifikasi pada bahan kuliner dan kandungan zat makanan. Klasifikasi secara umum, membagi beberapa makan menjadi kelompok hidangan pokok, makanan ringan, sambal dan minuman.

Klasifikasi perlu dilakukan untuk mengetahui positioning kuliner tersebut dalam tatanan prosesi makan. Makanan tidak dapat terlepas dari kehidupan sosial masyarakat. Makanan akan selalu hadir dalam setiap kegiatan kemasyarakatan oleh sebab itu mengklasifikasikan makanan menurut fungsi sosialnya menjadi penting dalam pengembangan budaya kuliner. Selain memiliki fungsi sosial, makanan juga merupakan refleksi dari rentetan sejarah masyarakat di sebuah wilayah, dimana seringkali terjadi akulturasi budaya yang menyebabkan munculnya jenis kuliner baru yang pada perkembangannya menjadi identitas dari kekayaan budaya yang dimiliki wilayah tersebut. Klasifikasi berikutnya yaitu berdasarkan nilai pembaharuan dan modifikasi. Hal ini penting untuk diidentifikasikan untuk kemudian mencari alternatif strategi dalam mengembangkan kuliner tradisional lebih lanjut. Kurangnya pasokan bahan baku, sulit ditemukannya alat masak tradisional dan alat penyajian membuat banyak pengrajin kuliner beralih pada alat-alat modern. Selain itu tuntutan pasar seringkali menggiring pengrajin dan pemasar kuliner tradisional untuk memodifikasi rasa dan tampilan kuliner tradisional. Hal ini tidak sepenuhnya salah, hanya saja perlu dipikirkan lebih lanjut cara menjaga originalitas dan ke-otentik-an dari kuliner tradisional.

Klasifikasi secara umum membagi jenis kuliner kedalam empat bagian yaitu hidangan pokok, makanan ringan, sambal dan minuman. Hidangan pokok merupakan seperangkat hidangan yang terdiri dari makanan pokok, sayur dan lauk pauk. Hasil penelitian tahap satu berhasil mengidentifikasikan bahwa dari ke-150 jenis Kuliner Tradisional Betawi yang teridentifikasi terdapat 59 jenis makanan yang termasuk dalam hidangan pokok. Makanan ringan atau makanan selingan merupakan jenis makanan yang dikonsumsi diantara waktu makan (hidangan pokok) dan dalam penelitian teridentifikasi terdapat 79 jenis makanan ringan. Sub klasifikasi berikutnya dalah sambal. Sambal merupakan hidangan pelengkap yang umumnya memiliki rasa pedas karena menggunakan cabai sebagai bahan utamanya. Teridentifikasi terdapat 3 jenis sambal yang merupakan sambal tradisional Betawi dan 9 jenis minuman.

Pada fungsi sosial, peneliti membagi menjadi tiga sub-klasifikasi yaitu acara khusus pada fase kehidupan, lebaran dan makanan sehari-hari. Masyarakat Betawi secara umum mengenal enam fase dalam kehidupan dan kesemuanya tidak lepas dari keberadaan kuliner baik sebagai pelengkap maupun simbol dalam acara tersebut. Dalam penelitian, teridentifikasi terdapat 67 jenis kuliner yang selalu digunakan dalam acara dalam fase kehidupan masyarakat betawi.

Selain fase kehidupan, kuliner juga selalu hadir pada kegiatan religi seperti pada saat "lebaran". Terdapat 23 jenis kuliner yang selalu hadir pada saat "lebaran" seperti, Sayur Godok, Semur Daging, Rendang Betawi, Serondeng, Ayam Sempyok, Ayam Goreng, Ayam Bakar, Gulai dan Dendeng Betawi sebagai hidangan pokok, serta makanan ringan seperti, biji ketapang, kue jahe, dodol betawi, kue satu, sagon, kembang goyang, kuping gajah, semprit, tape uli, rengginang, Wajik, Kue Akar Kelape, Manisan pepaya dan kolang kaling. Selain kedua sub-klasifikasi, banyak terdapat jenis Kuliner Tradisional Betawi yang merupakan makanan sehari-hari (terdapat 60 jenis kuliner). Bahkan fenomena saat ini banyak jenis kuliner yang dulu merupakan kuliner yang khusus disajikan pada acara tertentu, kini menjadi kuliner yang disajikan sehari-hari. Kuliner mencerminkan sejarah panjang perjalanan terbentuknya sebuah 
masyarakat pada suatu wilayah. Betawi merupakan akulturasi dari beberapa budaya di dunia termasuknya adalah budaya Timur Tengah, Eropa dan Cina, selain itu terdapat beberapa Kuliner Tradisional Betawi yang memiliki nilai sejarah secara ekologis. Terdapat empat jenis Kuliner Tradisional Betawi yang mengadaptasi budaya Eropa yaitu, Bir Pletok, Kue Cubit, Kue Leker, Semur Jengkol, Semur Daging dan Semur Terung Betawi. Kue Cubit memiliki kemiripan dengan poffertjes, panekuk mini yang diperkenalkan Belanda ketika menjajah bumi nusantara. Kue Leker, secara bahan dan pengolahannya merupakan makanan asli nusantara, hanya saja pada penamaan Leker (Belanda: Lekker, yang berarti enak). Sedangkan Semur berasal dari bahasa Belanda 'smoor' yang berarti rebusan. Di Indonesia, smoor berkembang dari sekadar rebusan daging sapi dengan tomat dan bawang menjadi masakan kaya bumbu dengan berbagai bahan dasar alternatif.

Berdasarkan hasil penelitian terdapat enam kuliner yang mengadaptasi kuliner Timur Tengah, mereka adalah; Nasi Kebuli, Kue Kamir, Gulai Kambing, Nasi Bukhari, Alie Bagente dan Kue Abug. Selain itu terdapat empat jenis kuliner hasil adaptasi dari budaya Cina yaitu Laksa, Hungkue, Mie Juhi dan Sayur Godok. Laksa dan Mie Juhi merupakan kuliner dengan bahan dasar mie, dimana sesuai catatan sejarah, mie pertama kali dibuat di daratan Cina sekitar 2000 tahun yang lalu pada masa pemerintahan Dinasti Han, dalam perkembangannya dengan masuknya budaya Cina ke Indonesia khususnya Jakarta, bahan dasar mie mulai mewarnai Kuliner Tradisional Betawi. Selain itu terdapat juga Sayur Godok, sayur yang menjadi hidangan wajib pada acara kemasyarakatan pada komunitas Suku Betawi, memiliki kemiripan dengan sayur godok yang selalu dihidangkan dalam Cap Go Meh yang melambangkan hari ke-15 dan hari terakhir dari masa perayaan Tahun Baru Imlek bagi komunitas Tionghoa di seluruh dunia. Selain itu terdapat juga tujuh jenis Kuliner Tradisional Betawi yang memiliki sejarah ekologis, seperti; Kerak Telor, Nasi Uduk, Sagon, Kue Akar Kelape, Pecak Tembang, Gabus Pucung, Gabus Garang Asem, Telubuk Sayur dan Tukis Daun Duren. Makanan dengan bahan dasar kelapa merupakan hasil pengolahan hasil bumi (kelapa) yang banyak terdapat di daerah Cikini dan sekitarnya. Beberapa bahan kuliner seperti bunga duren, pucung dan aren merupakan hasil pengolahan hasil bumi. Tuak yang merupakan hasil dari pohon nira yang saat itu banyak ditemukan di daerah Condet, Pondok Gede dan beberapa wilayah pinggiran Jakarta, sedangkan pecak tembang memiliki nilai sejarah bahwa pada pecak tembang merupakan pengolahan ikan asin (jenis bahan makanan murah) menjadi lebih enak.

Beberapa jenis Kuliner Tradisional mengalami perubahan baik alat masak yang digunakan, proses pembuatan, alat penyajian dan prosesi penyajian kuliner tersebut. Pada penelitian diketahui bahwa hampir semua jenis kuliner tradisional saat ini dimasak dengan tidak menggunakan alat tradisional sebagaimana dahulu kuliner tersebut dimasak. Hal ini paling tidak menunjukkan dua hal, yaitu kurangnya suplai alat masak tradisional dan sedikitnya minat masyarakat khususnya pengrajin kuliner untuk menggunakan dan melestarikan penggunaan alat masak tradisional. Hampir 25\% jenis kuliner telah mengalami pembaharuan dalam proses produksi, dan lebih dari 33\% telah mengalami perubahan dalam penggunaan alat penyajian dan proses penyajiannya. Banyaknya alat masak dan alat makan modern yang memberikan kemudahan bagi penggunanya membuat peralatan tradisional mulai ditinggal. Sedangkan pada sisi lain, mempertahankan originalitas makanan tradisional bukan hanya pada rasa, bentuk dan kemasan saja, tetapi lebih jauh lagi.

Mempertahankan kuliner tradisional juga bagian dari konservasi budaya, termasuk pada peralatan dan perlengkapan yang digunakan. Mempertahankan originalitas kuliner menjadi sulit saat ini mengingat banyak keterbatasan baik dari bahan 
makanan hingga bahan membuat alat masak. Tetapi menjaga originalitas menjadi hal utama dalam konsep konservasi budaya.

Modifikasi kuliner tradisional tidaklah sepenuhnya keliru, hanya saja modifikasi yang berlebihan hanya akan menjauhkan kuliner tradisioanal dari bentuk dan rasa aslinya. Beberapa Kuliner Tradisional Betawi telah mengalami perubahan bentuk, sebagai contoh roti buaya yang saat ini dibuat dalam bentuk yang kecil dan dapat dikonsumsi kapan saja (diluar acara pernikahan) dan beberapa jenis kue yang saat ini dibuat dalam ukuran yang lebih kecil, kue sagu yang saat ini dikemas dalam plastik gelas kecil, bir pletok dan nira saat ini dikemas dengan menggunakan botol plastik, Selain itu banyak terdapat 59 kuliner yang mengalami perubahan bahan baku.

Mayoritas makanan asli Betawi khususnya makanan ringan terbuat dari tepung beras maupun tepung ketan, tetapi saat ini mulai diganti dengan terigu. Perkembangan teknologi pangan banyak merubah pola memasak pada masyarakat, teknologi beberapa bahan pangan dan bumbu serta produksi bumbu jadi menjadikan masyarakat banyak menggantikan bumbu basah dengan bumbu kering dan bumbu jadi. Hal yang sama terjadi pada bahan pelengkap kuliner. Terdapat 69 jenis kuliner yang mengalami modifikasi pada bahan pe- lengkapnya, sebagai contoh es campur yang dulu menggunakan buah-buahan kini digantikan dengan agar rasa buah, selain itu penggunaan daun sebagai pembungkus makanan, kini mulai tergantikan.

Selain klasifikasi umum, fungsi sosial, sejarah, pembaharuan dan modifikasi, penelitian juga mengklasifikasikan Kuliner Tradisional Betawi berdasarkan kandungan gizinya. Karbohidrat yang terkandung dalam makanan bukan hanya bersumber dari makanan pokok yang menjadi bahan utamanya, tetapi jenis tepung juga menjadi sumber karbohidrat. Jenis vitamin berasal dari sayuran dan buah-buahan yang digunakan dalam masakan, dan protein baik hewani maupun nabati bersumber dari lauk pauk yang menjadi bagian dari hidangan pokok dan beberapa digunakan sebagai bahan pelengkap dalam makanan selingan. Selain itu hasil studi juga menemukan beberapa jenis kuliner yang telah dimodifikasi, baik mengalami modifikasi pada bentuk, bahan baku, bumbu maupun alat pelengkapnya, ternyata Kuliner Tradisional Betawi juga mengalami banyak perubahan, diantaranya pembaharuan pada alat masak, proses memasak, alat penyajian dan prosesi penyajiannya.

Hasil ekstrasi dari klasifikasi Kuliner Tradisional Betawi terlihat dalam Tabel 1 berikut.

Tabel 1

Ekstraksi Hasil Inventarisasi Kuliner Tradisional Betawi

\begin{tabular}{lll}
\hline \hline & Aspek & Jumlah \\
\hline Klasifikasi & Hidangan Pokok & 64 \\
Secara & Makanan Ringan & 73 \\
Umum & Sambal & 3 \\
& Minuman & 10 \\
Fungsi Sosial & Acara khusus pada fase kehidupan & 52 \\
& Lebaran & 23 \\
& Makanan sehari-hari & 90 \\
Nilai Sejarah & Adaptasi Budaya Timur Tengah & 6 \\
& Adaptasi Budaya Eropa & 4 \\
& Adaptasi Budaya Cina & 2 \\
& Memiliki Nilai Sejarah pada Ekologi Budaya Betawi & 9
\end{tabular}




\begin{tabular}{lll}
\multicolumn{2}{l}{ Lanjutan Tabel 1 } & \\
Nilai & Mengalami pembaharuan pada alat masak & 147 \\
Pembaharuan & Mengalami pembaharuan pada proses & 5 \\
& Mengalami pembaharuan pada alat penyajian & 22 \\
Modifikasi & Mengalami pembaharuan pada prosesi penyajian & 60 \\
kuliner & Mengalami modifikasi pada bentuk & 13 \\
& Mengalami modifikasi pada bahan baku & 0 \\
& Mengalami modifikasi pada bumbu & 13 \\
Kandungan & Mengalami modifikasi pada bahan pelengkap & 19 \\
zat makanan & Mengandung Karbohidrat & 87 \\
& Mengandung Vitamin & 58 \\
& Mengandung Protein Hewani & 150 \\
& Mengandung Protein Nabati & 57 \\
\hline
\end{tabular}

Sumber : Data primer (2017)

Makanan merupakan salah satu kebutuhan pokok, begitu juga pada masyarakat Betawi. Pada masyarakat Betawi nasi perupakan makanan pokok sebagai asupan karbohidrat, selain itu tambahan sayur mayur dan buah-buahan yang banyak didapatkan dari kebun merupakan sumber vitamin, protein dan mineral bagi masyarakat Betawi. Sedangkan kebutuhan lemak didapatkan dari hewan-hewan ternak. Kuliner selalu lekat dengan kehidupan sosial budaya masyarakat, begitu juga pada masyarakat Betawi. Pada Budaya Betawi terdapat beberapa perayaan atau upacara sesuai dengan daur hidup manusia, dari dalam kandungan, lahir, bayi, masa kanakkanak, remaja, menikah dan meninggal dunia.

Fase Kandungan. Pada fase ini Masyarakat Betawi mengenal sebuah acara yang dinamakan "nujuh bulanan", upacara yang berkaitan dengan masa kehamilan 7 bulan. Nujuh diambil dari jumlah hari yang berjumlah 7 hari. Bilangan tujuh dipakai sebagai patokan pada upacara nujuh bulan. Maksud upacara untuk mendapatkan rasa aman dengan membaca Al-Quran surah Yunus dan Maryam. Agar anaknya jika perempuan akan secantik Maryam dan Nabi Yunus as serta memohon keberkahan dan perlindungan pada-Nya agar anak yang akan dilahirkan kelak bisa lahir dengan selamat, menjadi anak yang sholeh, berbudi luhur dan patuh kepada kedua orang tuanya. Kuliner yang wajib pada acara ini adalah rujak yang terdiri dari 7 macam buah-buahan, yaitu: buah delima, mangga muda, jeruk merah (jeruk Bali), pepaya mengkal, bengkuang, kedondong, ubi jalar, serta bumbu rujak yang terdiri dari gula merah (gula jawa), asam jawa, cabe rawit, garam, terasi, dan lain-lain. Buah delima merupakan salah satu buah yang wajib ada pada rujak nujuh bulanan, begitu juga jeruk bali merah. Menurut mereka, buah delima yang masak dan berwarna merah akan membuat bayi yang akan dilahirkan kelak sangat menarik dan disenangi orang. Jeruk Bali merah mempunyai maksud tersendiri. Jeruk merah biasanya rasanya manis dan enak dibuat rujak, dan bila dikupas kulitnya mudah terkelupas. Hal ini diumpamakan agar bayi yang akan dilahirkan kelak akan mudah dan lancar serta tidak mengalami kesulitan, semudah mengupas jeruk merah tersebut. Fase Lahiran. Pada fase ini bayi baru dilahirkan, dan masyarakat Betawi mengenal prosesi "mapas". Upacara yang dilakukan apabila ada seorang ibu yang baru melahirkan. Pada upacara ini, si ibu yang baru melahirkan diharuskan memakan "sayur papasan" yang isinya terdiri dari berbagai macam sayur mayur agar si ibu tetap sehat, demikianjuga bayi yang baru dilahirkannya. 
Fase Bayi. Masa bayi disebut sebagai salah satu fase terpenting karena selama masa ini seorang individu mulai belajar dan memahami berbagai macam hal-hal. Fase bayi diawali dari lahirnya seorang manusia di muka bumi. Sebagai masyarakat yang religius Masyarakat Betawi melaksanakan syariat islam yaitu akikah, selain itu Masyarakat betawi juga melaksanakan prosesi puputan.

Puput Puser. Prosesi puput puser atau "puputan" adalah suatu upacara yang dilakukan apabila tali pusat bayi sudah lepas (puput). Orang Betawi mengadakan selamatan ala kadarnya. Biasanya masyarakat Betawi akan menyediakan Nasi kuning dengan lauk-pauknya dan bagi yang memiliki kemampuan lebih akan memasak ayam sempyok sebagai tambahan.

Akikah. Upacara selametan untuk anak yang baru dilahirkan dengan memotong kambing, laki-laki 2 ekor kambing, perempuan 1 ekor kambing. Seperti yang diajarkan juga dalam agama Islam. Serta upacara bagi anak bayi berusia 40 hari, yaitu upacara mencukur rambut bayi. Selain itu biasanya masyarakat Betawi mengadakan acara pengajian dan membagikan Nasi Berkat (besek) yang terdiri dari nasi, lauk pauk, buah dan kerupuk kepada tetangga atau sanak saudara yang menghadiri acara tersebut. Daging kambing yang telah dipotong tersebut akan dimasak gulai atau disate dan kemudian di bagikan pada tetangga dan kerabat.

Fase Anak- anak. Pada saat ini sang bayi telah tumbuh dan telah mencapai usia kanak-kanak. Masyarakat Betawi merupakan masyarakat dengan mayoritas sebagai pemeluk Agama Islam yang cukup taat, oleh sebab itu, pada fase ini Masyarakat Betawi mengenal dua macam prosesi yaitu sunatan (bagi anak laki-laki) dan acara khatam Al'Quran.

Sunatan. Di masyarakat Betawi, sunat diartikan sebagai pembeda. Maksudnya, pembeda usia antara anak-anak dengan seseorang yang sudah akil balig. Orang tuanya berembuk atau berdiskusi dan ber- musyawarah dengan tetua atau sesepuh kampung untuk melaksanakan upacara sunat. Pada acara ini kuliner yang biasa disajikan adalah nasi kuning Betawi yang terbuat dari beras ketan dan lauk pauknya berupa semur daging, acar kuning, serondeng, bawang goreng, dan emping melinjo, selain itu pada masyarakat Betawi dalam kategori mampu biasanya akan menambah dengan ayam sempyok.

Khataman. Masyarakat Betawi adalah masyarakat yang religius. Sejak kanak-kanak anak-anak Suku Betawi telah dikenalkan dengan pendidikan agama khususnya mengaji, sehingga tidak heran jika banyak ditemukan anak-anak yang sudah khatam $\mathrm{Al}^{\prime}$ Quran. Dan bagi orang tua, sebuah kebanggaan saat anaknya sudah khatam $\mathrm{Al}^{\prime}$ Quran sehingga biasanya masyarakat Betawi akan membuat acara "slametan Khataman". Khatam Qur'an di Betawi sering disebut Tamatan Qur'an. Upacara ini sangat penting bagi orang Betawi karena ini sebagai pertanda bahwa seseorang yang sudah melaksanakan upacara Tamatan Qur'an dianggap telah menjadi orang yang mengerti ajaran agama Islam. Pada prosesi ini kuliner yang disajikan adalah nasi kuning atau nasi uduk dengan lauk pauknya. Beberapa orang tua membuat nasi tumpeng

Fase Dewasa. Pada fase ini seorang pada komunitas Betawi telah dianggap matang baik secara psikologis maupun biologis, sehingga pada fase ini acara-acara yang dilakukan terkait dengan prosesi pernikahan. Pada fase dewasa mengenal tujuh prosesi yaitu; ngedeleng, ngelamar, bawe tande putus, sebar undangan, ngerudut, akad nikah, kebesaran, negot dan pulang tige ari.

Ngedelegin. Ngedelegin adalah mencari calon menantu perempuan yang di lakukan oleh Mak Comblang. Biasanya pada acara ini keluarga calon besan akan menyediakan teh atau kopi dan kue-kue tradisional.

Ngelamar. Pada prosesi lamaran pikah lelaki menyatakan permintaan pinangan kepada pihak perempuan. Pada acara ini dikenal istilah "Kue bacot" yaitu pemberian kue tradisional khas Betawi seperti wajik, 
dodol, geplak dan manisan kolang-kaling. Tradisi kue bacot diadakan setelah prosesi lamaran dari calon mempelai pria. Kue bacot diberikan pihak wanita kepada pihak pria sebagai balasan hantaran saat acara lamaran. Selain itu, kue tradisional tersebut juga boleh diberikan kepada tetangga sekitar rumah mempelai wanita dengan maksud pemberitahuan bahwa akan ada hajatan pernikahan dalam waktu dekat.

Pada prosesi lamaran adat Betawi yang harus disiapkan adalah: Sirih lamaran, pisang raja, roti tawar, hadiah pelengkap dan Para utusan yang tediri atas Mak Comblang, Dua pasang wakil orang tua dari calon tuan mantu terdiri dari sepasang wakil keluarga ibu dan bapak.

Bawa Tende Putus. Bawe tande putus merupakan pernyataan atau kesepakatan kapan pernikahan akan dilaksanakan. Pada prosesi ini biasanya keluarga calon besan menyediakan kue tradisional dan kopi atau teh sebagai sajian pada saat musyawarah keluarga tersebut.

Sebar Undangan. Saat tanggal pelaksanaan akad dan kebesaran (resepsi) telah ditentukan makan berikutnya adalah penyebaran undangan. Pada prosesi ini Masyarakat Betawi mengenal istilah "Nasi Jotan". Adapun rupa nasi jotan antara lain: nasi putih, ketan kuning bertabur serundeng, acar wortel dan ketimun, tumis buncis dan ikan bandeng bakar. Nasi jotan merupakan sebuah pemberian makanan dari keluarga mempelai wanita kepada tokoh masyarakat dan orang yang dituakan di kampung tersebut. Nasi jotan tersebut biasanya diberikan sehari sebelum hajat nikah dilaksanakan. Pada beberapa masyarakat Betawi membagikan rokok sebagai tanda jika si penerima diundang untuk menghadiri acara akad atau resepsi.

Ngerudat. Ini merupakan prosesi dimana rombongan keluarga pengantin laki-laki menuju rumah pengantin perempuan, seraya membawa serah-serahan seperti roti buaya, pesalin, sie, dan lain-lain. Prosesi ngerudat biasanya mengawali prosesi berikutnya yaitu akad nikah.
Akad Nikah. Akad nikah merupakan ikrar yang diucapkan oleh pengantin lakilaki di hadapan wali pengantin perempuan. Serangkaian acara akad nikah biasanya akan diawali dengan prosesi "Palang Pintu". Pada prosesi ini biasanya keluarga mempelai wanita akan menyediakan "Sayur Besan" sebagai penghormatan kepada besan.

Kebesaran. Kebesaran atau saat ini biasa disebut resepsi, upacara kedua mempelai duduk di puade untuk menerima ucapan selamat dari keluarga dan undangan. Acara ini biasanya keluarga kedua mempelai akan mengundang sanak saudara, rekan-rekan dan tetangga untuk bersama-sama berbagi kebahagiaan. Pada proses ini keluarga mempelai wanita akan menyediakan beberapa jenis makan sebagai bentuk ungkapan terima kasih atas doa restu yang diberikan, kuliner yang biasa disajikan adalah : nasi uduk beserta lauk pauknya, kopi, teh, buah buahan, ketan kuning bertabur serondeng, tape uli dan beberapa jenis kue tradisiosnal. Tetapi pada perkembangannya, saat ini tidak ada yang membedakan resepsi pernikahan Suku Betawi dan di luar Betawi karena kuliner yang disediakan pada setiap kegiatan sosial masyarakat termasuk pada prosesi pernikahan cenderung homogen dengan menyediakan variasi kuliner yang tergolong standar.

Negor. Prosesi berikutnya adalah negor, dimana prosesi ini merupakan upaya suami merayu istrinya untuk memulai hidup baru sebagai sebuah keluarga. Prosesi ini juga menjadi sangat sakral dan berarti bagi kehidupan kedua manusia yang akan bersama-sama membangun rumah tangga, dan menjadi bukti kesucian wanita sebagai istri.

Pulang Tige Ari. Pulang tiga ari dilaksanakan saat pengantin laki-laki telah tiga hari menginap di rumah pengantin wanita. Acara ini diadakan di rumah keluarga pengantin lelaki sebagai ungkapan kegembiraan keluarga pengantin laki-laki bahwa saat ini anak mereka telah menjadi seorang imam bagi keluarganya. Pada saat pengantin laki-laki akan disuguhi teh atau kopi dan makanan kecil sebagai cemilan. 
Fase Kematian. Upacara Kematian atau Haul atau tahlilan, diselenggarakan oleh para anggota keluarga apabila ada kematian. Mengadakan selamatan atau sedekahan, selamatan semacam ini juga diadakan pada waktu yang meninggal telah mencapai 7 hari, 40 hari, 100 hari, dan 1000 hari dari saat meninggalnya. Jenis kuliner yang biasa di sajikan pada fase ini adalah: (1) Nasi begané. Disebut nasi begané karena nasi putih dengan lauk-pauk utamanya adalah begané. Masakan begané adalah tumis kering ayam cacag; (2) Tige ari disediakan dadar gulung, Tuju ari disediakan nasi biasa lengkap. Malam lima belas disediakan ketupat sayur. Malam empat puluh disajikan ketupat sayur laksa dan sate pentul; (3) Pada acara haul (peringatan 1000 hari) umumnya orang kaya menyediakan nasi kebuli dan pacri. Untuk keluarga, kerabat ataupun tetangga yang mendapat kabar duka maka akan mengunjungi keluaga yang berduka. Pada Masyarakat betawi dikenal dengan istilah "nyelawat".

Selain kelima fase tersebut, masyarakat Betawi juga mengenal tiga acara sosial dan religi, yaitu; bikin/pinde rume, Nazar dan Lebaran. Bikin dan Pinde Rume dilakukan saat orang Betawi akan melakukan pembangunan rumah dan pindah ke rumah yang baru. Sebagai masyarakat yang memiliki nilai kekerabatan yang cukup erat, maka prosesi ini biasanya akan dibuatkan sebuah perayaan tersendiri yaitu diadakannya pengajian dan membagikan nasi berkat yang isinya nasi kebuli, nasi uduk dan kue tradisional Betawi. Prosesi berikutnya adalah nazar. Masyarakat Betawi pinggir menyebutnya "ngucap" dan "kaulan" merupakan janji yang diniatkan dalam hati dan diucapkan dengan tegas serta dapat didengar oleh orang disekitamya. Nazar itu harus dilaksanakan sesuai janji manakala tidak dilaksanakan akan berakibat buruk bagi si nazar, tidak ada informasi yang jelas terkait kuliner yang digunakan pada acara ini karena setiap nazar orang berbeda-beda. Yang terakhir adalah acara lebaran. Bagi orang Betawi, lebaran adalah salah satu puncak kegembiraan setelah menjalankan masa bakti dan ketakwaan. Untuk sampai pada tahap lebaran beberapa tahap lagi yang harus dilalui dengan baik dan benar. Orang Betawi mengenal paling sedikit tiga macam lebaran, yaitu lebaran Idul Fitri, Lebaran Haji, dan Lebaran Anak Yatim. Masyarakat Betawi mayoritas beragama islam, sehingga pada perayaan Lebaran masyarakat Betawi akan menyediakan makan besar bagi keluarga dan sanak saudara bahkan para tetangga. Makanan yang biasa disajikan pada saat lebaran adalah: Pesor, Ketupat, Sayur Goduk, Tape Uli, Kembang Goyang, Kue Jahe, Biji ketapang, Kue Kuping Gajah, Rendang Betawi, Serondeng, Ayam Sempyok, Kue Semprit, Kue, Satu, Sagon, Nasi Briani, Nasi Kebuli, Dodol, Kolang kaling.

Selain makanan yang telah disebutkan pada beberapa jenis prosesi di atas, Budaya Betawi juga memliki variasi varian sambal, yaitu; Sambelan Lengkio, Sambal Honjo dan Sambal Kencur. Ketiga jenis sambel tersebut pernah populer pada Masyarakat Betawi. Sambal Lengkio dengan bahan baku utamanya adalah Lengkio. Lengkio atau Lo kio, atau Chives (Allium Schoenoprasum) adalah keluarga bawang-bawangan yang berukuran mini. Memiliki umbi lapis yang serupa dengan bawang merah. Bedanya, bawang kecil ini berwarna putih kehijauan, sedangkan bawang merah jika kering lapis umbi terluarnya berwarna merah dan daunnya panjang, sekitar 10-15 cm dan rasanya sangat khas. Saat ini Lengkio sulit untuk didapatkan terutama di kota besar, tetapi kadang masih dapat ditemukan pada pasar-pasar tradisional. Jenis sambal berikutnya adalah Sambal Honjo. Bahan baku utamanya adalah Honjo. Honje (Etlingera elatior) atau Kecombrang, kantan adalah sejenis tumbuhan rempah dan merupakan tumbuhan tahunan berbentuk terna yang bunga, buah, serta bijinya dimanfaatkan sebagai bahan sayuran. Nama lainnya adalah kincung (Medan) sambel kincung, kincuang dan sambuang (Minangkabau) serta siantan (Malaya). Orang Thai menyebutnya kaalaa dan di Bali disebut 
kecicang. Sambal Honjo memiliki kemiripan dengan jenis sambal yang sangat populer di daerah Pandeglang, Banten.

Overlay jenis kuliner pada sebuah daerah dengan daerah lainnya adalah hal yang sangat wajar mengingat kuliner adalah produk budaya, dan budaya diturunkan dan akan berpindah mengikuti mobilitas masyarakat tersebut. Dan yang terakhir adalah sambal kencur dengan bahan baku utamanya adalah kencur. Kekhasan dari sambal ini adalah sambalnya berwarna kekuningan sesuai dengan warna kencur. Rasanya yang sedikit getir membuat sambal ini memiliki keunikan rasa tersendiri dan untuk mengurangi rasa getir dari kencur biasanya kencur dibakar atau disangrai terlebih dahulu. Saat ini jenis sambal ini sudah sangat sulit untuk ditemukan, terlebih lagi dengan maraknya sambal instan, makin menjauhkan popularitas jenis sambal tersebut.

Pada saat ini variasi jenis kuliner ini sulit untuk ditemukan, setidaknya terdapat dua permasalahan pokok yaitu 1). Tidak ada lagi yang memasak dan 2). Kuliner dirasa kurang menarik baik secara rasa maupun tampilan sehingga masyarakat kurang menerima atau dengan kata lain jenis kuliner tersebut tidak diminati oleh masyarakat. Pada permasalahan pertama, tidak adanya masyarakat yang memasak bukan hanya karena pengolahan yang sulit, tapi bahan baku yang sulit untuk ditemukan, alat pengolahan yang kini sulit untuk ditemukan atau alat pelengkap tradisional yang ini mulai berganti juga menjadi permasalahan mengapa saat ini jarang atau bahkan tidak ada masyarakat yang memasak jenis kuliner tersebut. Kemudian untuk permasalahan kedua, kuliner dirasa kurang menarik baik secara rasa maupun tampilan, persepsi demikian yang akhirnya menggerus originalitas dari sebuah kuliner tradisional.

Kuliner tradisional mulai diadaptasi dengan selera modern sehingga munculkan jenis-jenis kuliner fussion. Secara sosial apalagi bisnis, hal ini tidak salah, karena inilah dinamika masyarakat modern, dan beginilah konsekuensi pasar dimana pe- masar harus menyesuaikan selera pasar. Tapi jika dipandang dalam frame budaya, hal tersebut menjadi keliru dan membahayakan, karena hal ini yang menyebabkan masyarakat semakin jauh dari budaya akarnya. Realita tersebut dapat dilihat secara empirik pada saat ini dimana masyarakat lebih mengenal dan tertarik untuk mengkonsumsi kuliner asing atau fussion dibanding dengan kuliner tradisional, dan ini juga terjadi pada Masyarakat Betawi.

Terjadi pergeseran fungsi dari beberapa makanan selingan yang ada di DKI Jakarta, perkembangan jaman membuat beberapa jenis makanan yang awalnya hanya dapat ditemui pada acara atau moment seremonial tertentu saat ini difungsikan sebagai kuliner atau makanan sehari-hari. Selain itu banyak terdapat jenis variasi Kuliner Tradisional Betawi yang sama dengan Kuliner Tradisional dari wilayah lain seperti Jawa Barat, Jawa Tengah, bahkan terdapat beberapa kuliner yang sama dengan jenis kuliner yang terdapat di Sulawesi dan Sumatra. Hal ini dapat terjadi karena kuliner adalah salah satu produk budaya, dimana kebudayaan sebagai aktifitas atau pola tindakan manusia dalam masyarakat dan kebudayaan nonmaterial adalah ciptaan-ciptaan abstrak yang diwariskan dari generasi ke generasi. Kuliner adalah produk seni yang merupakan hasil cipta rasa dan karsa manusia dan sangat dipengaruhi oleh lingkungan sekitarnya.

\section{Strategi Pengembangan Ekowisata Kuliner Tradisional Betawi di DKI Jakarta}

Strategi dan kebijakan yang akan dicanangkan sebagai pemandu arah sekaligus pedoman untuk mencapai sasaran-sasaran sebagaimana telah dikemukakan dilakukan dengan melakukan analisis manajemen strategik. Sesuai dengan pengertiannya dimana strategi merupakan pendekatan yang dilakukan secara keseluruhan, berkaitan dengan pelaksanaan gagasan, perencanaan, dan eksekusi dari sebuah aktivitas, maka penelitian terbagi menjadi tiga proses yaitu, input, matching dan output. Pada proses 
input, peneliti menggunakan matriks EFAS/ IFAS, kemudian dilanjutkan dengan Grand Matriks dan Matrik SWOT.

Pada analisis manajemen strategik akan diperoleh berbagai faktor yang membentuk dan mempengaruhi terhadap pengembangan Ekowisata Kuliner Tradisional betawi di DKI Jakarta yag digolongkan ke dalam faktor eksternal (peluang dan ancaman) atau dapat dikatakan dampak secara langsung (direct impact) sedangkan dampak yang ditimbulkan tidak secara langsung digolongkan ke dalam faktor internal (kekuatan dan kelemahan) disebut indirect impact. Dua dampak yang didapatkan adalah dampak positif tersebut yang berasal dari peluang dan kekuatan dan dampak negatif yang berasal dari ancaman dan kelemahan. Dalam penyususnan strategi lebih lanjut akan dibagi menjadi 4 model strategi, yaitu
Model Strategi Pengembangan Kuliner Familiar, Model Strategi Pengembangan Kuliner Recall dan Model Strategi Pengembangan Kuliner Pastknown dalam Pengembangan Ekowisata Kuliner Tradisional Betawi di DKI Jakarta.

\section{Model Strategi Pengembangan Kuliner Familiar.}

Berdasarkan hasil studi terdapat 6 jenis kuliner yang masuk dalam kategori familliar. Mayoritas ke-6 kuliner tersebut adalah kuliner rumahan dan bahan baku maupun bumbu pelengkap kuliner masih cukup mudah didapatkan, selain itu proses produksinyapun relatif sangat mudah, sehingga sampai saat ini eksistensinya masih sangat terjaga. Tabel 2 merupakan formulasi matrik IFAS/EFAS dari kuliner familiar.

Tabel 2

Matriks EFAS IFAS Kuliner Familiar

\begin{tabular}{lccc}
\hline \hline \multicolumn{1}{c}{ Internal Faktor } & Bobot & Rank & Total \\
\hline Kekuatan & & 3 & 0,3 \\
\hline $\begin{array}{l}\text { 1. Bahan baku ke-6 kuliner familiar kuliner Betawi } \\
\text { mudah didapatkan }\end{array}$ & 0,1 & 4 & 0,96 \\
$\begin{array}{l}\text { 2. Terdapat variasi kuliner Betawi yang sangat } \\
\text { besar; 150 jenis kuliner }\end{array}$ & 0,24 & 4 & 1,08 \\
3. Pengolahan ke-6 kuliner familiar relatif mudah & 0,27 & 3 & 0,45 \\
$\begin{array}{l}\text { 4. Jenis kuliner familliar secara disajikan secara } \\
\text { continue }\end{array}$ & 0,15 & 4 & 0,55 \\
5. Ke-6 jenis kuliner dalam kategori familiar adalah \\
$\begin{array}{l}\text { kuliner rumahan sehingga mudah untuk } \\
\text { ditemukan }\end{array}$ \\
$\begin{array}{l}\text { Sub Total } \\
\text { Kelemahan }\end{array}$
\end{tabular}


Lanjutan Tabel 2

6. Beberapa kuliner Betawi familiar sudah banyak

0,11

3

0,33

mengalami modifikasi dalam alat memasak dan penyajian

7. Belum maksimalnya teknologi dalam rekayasa produksi

\begin{tabular}{|c|c|c|c|}
\hline Sub Total & 1,0 & & 3,35 \\
\hline \multicolumn{4}{|l|}{ Eksternal Faktor } \\
\hline \multicolumn{4}{|l|}{$\begin{array}{ll}\text { Peluang } \\
\end{array}$} \\
\hline $\begin{array}{l}\text { 1. Pasar potensial ke-6 kuliner Betawi Familiar yang } \\
\text { sangat besar }\end{array}$ & 0,11 & 4 & 0,44 \\
\hline $\begin{array}{l}\text { 2. Sebagian dari kuliner Betawi Familiar adalah } \\
\text { makanan pokok bagi masyarakat Jakarta }\end{array}$ & 0,21 & 3 & 0,63 \\
\hline $\begin{array}{l}\text { 3. Ke-6 jenis kuliner Betawi Familiar sudah sangat } \\
\text { dikenal oleh masyarakat }\end{array}$ & 0,15 & 4 & 1,16 \\
\hline $\begin{array}{l}\text { 4. Trand kuliner Tradisional sedang banyak } \\
\text { diangkat oleh media }\end{array}$ & 0,12 & 2 & 0,24 \\
\hline $\begin{array}{l}\text { 5. Tersedianya dasar hukum sebagai landasan } \\
\text { operasional baik berupa perundang-undangan } \\
\text { maupun peraturandaerah }\end{array}$ & & & \\
\hline $\begin{array}{l}\text { 6. Berkembangnya para gourmands (pencinta } \\
\text { makanan dengan cita rasa khas) yang } \\
\text { menjadikan eksporasi rasa makanan menjadi } \\
\text { motivasi utama dalam mengkonsumsi kuliner }\end{array}$ & 0,12 & 2 & 0,24 \\
\hline $\begin{array}{l}\text { 7. Fakta bahwa kuliner tradisional memiliki nilai } \\
\text { kenangan yang sulit terganti oleh makanan } \\
\text { fussion maupun makanan modern lainnya }\end{array}$ & 0,15 & 3 & 0,45 \\
\hline Sub Total & 1,0 & & 2,88 \\
\hline \multicolumn{4}{|l|}{ Tantangan } \\
\hline $\begin{array}{l}\text { 1. Sulit menemukan alat masak yang asli untuk } \\
\text { mengolah ke-6 jenis kuliner Betawi Familiar }\end{array}$ & 0,21 & 4 & 0,84 \\
\hline $\begin{array}{l}\text { 2. Pergeseran pola konsumsi masyarakat sehingga } \\
\text { menggeser proses makan mengkonsumsi } \\
\text { beberapa jenis kuliner Betawi Familiar }\end{array}$ & 0,29 & 3 & 0,87 \\
\hline $\begin{array}{l}\text { 3. Kurangnya pemahaman nilai budaya Kuliner } \\
\text { Betawi sehingga beberapa kuliner Betawi } \\
\text { Familiar tidak disajikan sesuai dengan } \\
\text { peruntukannya }\end{array}$ & 0,18 & 2 & 0,36 \\
\hline $\begin{array}{l}\text { 4. Kurangnya minat masyarakat dalam pengolahan } \\
\text { kuliner Tradisional Betawi }\end{array}$ & 0,2 & 1 & 0,2 \\
\hline 5. Lemahnya koordinasi lintas sektoral & 0,12 & 3 & 0,36 \\
\hline Sub Total & 1,0 & & 2,63 \\
\hline
\end{tabular}

Sumber : Pengolahan data primer 2017, pemberian bobot merujuk pada proses compareing system yang mengadopsi konsep AHP (Analisis Hirarki Proses)

Berdasarkan matrik EFAS IFAS Kuliner umum variabel-variabel pada faktor internal Familiar tersebut dapat terlihat bahwa secara memiliki total score yang lebih tinggi (ke- 
kuatan 3,34 dan kelemahan 3,35) daripada variabel-variabel pada faktor eksternal (peluang 2,88 dan hambatan 2,63). Dengan demikian terlihat bahwa saat ini perkembangan Kuliner Tradisional Betawi pada kategori familiar di DKI Jakarta dipengaruhi oleh faktor internal, dengan kata lain posisioning strategis Kuliner Tradisional Betawi pada kategori familiar cukup kuat. Dalam serangkaian penyusunan strategi berikutnya adalah menuangkan hasil yang didapat pada matriks EFAS/IFAS pada Grand Matriks Strategi. Hal ini di tujukan agar mengetahui posisi Kuliner Tradisional Betawi Familiar pada kuadran Grand Matrik maka dalam penyususnan strategi lebih lanjut dapat lebih terarah. Berikut adalah bagan Grand Matriks Strategi

Hasil output Grand Matriks Strategi kemudian akan diaplikasikan dengan eksisting condition dalam pengembangan Kuliner Tradisional Betawi di DKI Jakarta. Pada proses matching ini menggunakan Matriks SWOT, dimana akan terbentuk beberapa kluster strategi yaitu SO (Strength; Opportunity), WO (Weakness; Opportunity), ST (Strength; Threat) dan WT (Weakness; Threat). Dari setiap cluster terdapat beberapa strategi yang kesemuanya diarahkan pada ketiga alternatif strategi sebagimana direkomendasikan pada grand matriks, yaitu: Product and market development, Market penetration dan Backward and forward integration. Product and market development merupakan usaha dalam mengembangkan target pasar baru dan meningkatkan nilai produk kuliner. Sedangkan market penetration adalah strategi fokus pada target pasar dengan mengembangakan startegi crossselling dan upselling. Backward dan foreward integration merupakan usaha untuk membangun kemitraan baik dengan supplyer maupun retailer produk kuliner.

Tabel 3

\section{Matriks SWOT Kuliner familiar}

\begin{tabular}{lll}
\hline \hline \multicolumn{1}{c}{ Kekuatan } & \multicolumn{1}{c}{ Kelemahan } \\
\cline { 2 - 3 } 1. Bahan baku ke-6 kuliner & 1. Sedikit sekali kuliner \\
familiar kuliner Betawi & Betawi yang masuk \\
mudah didapatkan & dalam kategori familiar; \\
2. Terdapat variasi kuliner & hanya 6 jenis kuliner \\
Betawi yang sangat & 2. Kurangnya promosi \\
besar;150 jenis kuliner & terhadap ke-6 produk \\
3. Pengelolaan ke- Kuliner & kuliner Betawi familiar \\
Familiar relatif mudah & 3. Pemasaran ke -6 produk \\
4. Jenis Kuliner Familiar & kuliner Betawi yang \\
disajikan secara & masih sangat tradisional \\
contuniu & 4. Tata kelola produksi ke - \\
5. Ke-6 jenis kuliner dalam & 6 kuliner Betawi belum \\
kategori familiar adalah & terstandarisasi \\
kuliner rumahan & 5. Pengemasan ke-6 kuliner \\
sehingga mudah untuk & Betawi familiar sangat \\
ditemukan & standar \\
& 6. Beberapa kuliner Betawi \\
& familiar sudah banyak \\
& mengalami modifikasi \\
& dalam alat memasak dan \\
& penyajian \\
\hline
\end{tabular}


7. Belum maksimalnya teknologi dalam rekayasa produksi

\begin{tabular}{|c|c|c|}
\hline Peluang & SO & WO \\
\hline $\begin{array}{l}\text { 1. Pasar potensial ke-6 } \\
\text { kuliner Betawi } \\
\text { Familiar yang sangat } \\
\text { besar } \\
\text { 2. Sebagian dari kuliner } \\
\text { Betawi Familiar } \\
\text { adalah makanan } \\
\text { pokok bagi } \\
\text { masyarakat Jakarta } \\
\text { 3. Ke-6 jenis kuliner } \\
\text { Betawi familiar } \\
\text { sudah sangat dikenal } \\
\text { oleh masyarakat }\end{array}$ & $\begin{array}{l}\text { a) Reorientasi produksi } \\
\text { makanan, dari makanan } \\
\text { rumahan menuju } \\
\text { produksi makanan yang } \\
\text { memiliki nilai ekonomis } \\
\text { b) Sosialisasi nilai soaial } \\
\text { budaya kuliner agar } \\
\text { pengembangan kuliner } \\
\text { yang ada mengarah ke } \\
\text { peningkatan } \\
\text { pengetahuan kuliner }\end{array}$ & $\begin{array}{l}\text { a) Fokus pada } \\
\text { pengembangan kuliner } \\
\text { familliar menjadikan ke } \\
\text { enam kuliner tersebut } \\
\text { sebagai icon } \\
\text { b) Mengembangan promosi } \\
\text { WOM } \\
\text { c) Sosialiasi proses } \\
\text { produksi yang } \\
\text { bertanggungjawab } \\
\text { d) Mengadakan pelatihan } \\
\text { untuk meningkatkan } \\
\text { SDM }\end{array}$ \\
\hline Peluang & SO & WO \\
\hline $\begin{array}{l}\text { 4. Pasar potensial ke-6 } \\
\text { kuliner Betawi } \\
\text { Familiar yang sangat } \\
\text { besar } \\
\text { 5. Sebagian dari kuliner } \\
\text { Betawi Familiar } \\
\text { adalah makanan } \\
\text { pokok bagi } \\
\text { masyarakat Jakarta } \\
\text { 6. Ke-6 jenis kuliner } \\
\text { Betawi familiar } \\
\text { sudah sangat dikenal } \\
\text { oleh masyarakat } \\
\text { 7. Trand kuliner } \\
\text { Tradisional sedang } \\
\text { banyak diangkat } \\
\text { oleh media } \\
\text { 8. Tersedianya dasar } \\
\text { hukum sebagai } \\
\text { landasan operasional } \\
\text { baik berupa } \\
\text { perundang- } \\
\text { undangan maupun } \\
\text { peraturandaerah } \\
\text { 9. Berkembangnya para } \\
\text { gourmands (pencinta } \\
\text { makanan dengan cita } \\
\text { rasa khas) yang } \\
\text { menjadikan } \\
\text { eksporasi rasa }\end{array}$ & $\begin{array}{l}\text { c) Reorientasi produksi } \\
\text { makanan, dari makanan } \\
\text { rumahan menuju } \\
\text { produksi makanan yang } \\
\text { memiliki nilai ekonomis } \\
\text { d) Sosialisasi nilai soaial } \\
\text { budaya kuliner agar } \\
\text { pengembangan kuliner } \\
\text { yang ada mengarah ke } \\
\text { peningkatan } \\
\text { pengetahuan kuliner } \\
\text { e) Pengembangan cluster } \\
\text { produsen dan cluster } \\
\text { pemasar kuliner } \\
\text { Memperkuat pengadaan } \\
\text { sumber bahan kuliner } \\
\text { untuk menjaga eksistensi } \\
\text { kuliner Betawi } \\
\text { f) Mengembangkan pasar } \\
\text { kuliner pada wilayah } \\
\text { sekitar DKI Jakarta }\end{array}$ & $\begin{array}{l}\text { e) Fokus pada } \\
\text { pengembangan kuliner } \\
\text { familliar menjadikan ke } \\
\text { enam kuliner tersebut } \\
\text { sebagai icon } \\
\text { f) } \\
\text { Wengembangan promosi } \\
\text { WOM } \\
\text { g) Sosialiasi proses } \\
\text { produksi yang } \\
\text { bertanggungjawab } \\
\text { h) } \text { Mengadakan pelatihan } \\
\text { untuk meningkatkan } \\
\text { kemampuan dan } \\
\text { pengetahuan dalam } \\
\text { meproduksi kuliner } \\
\text { i) } \text { Mengadakan event } \\
\text { workshop kuliner } \\
\text { Betawi Familliar untuk } \\
\text { memperkenalkan nilai } \\
\text { sosial budaya Kuliner } \\
\text { Betawi }\end{array}$ \\
\hline
\end{tabular}


makanan menjadi

motivasi utama

dalam

mengkonsumsi

kuliner

10.Fakta bahwa kuliner

tradisional memiliki

nilai kenangan yang

sulit terganti oleh

makanan fussion

maupun makanan

modern lainny

\begin{tabular}{|c|c|c|}
\hline Tantangan & ST & WT \\
\hline $\begin{array}{l}\text { 1. Sulit menemukan } \\
\text { alat masak yang asli } \\
\text { untuk mengolah ke-6 } \\
\text { jenis kuliner Betawi } \\
\text { Familiar } \\
\text { 2. Pergeseran pola } \\
\text { konsumsi } \\
\text { masyarakat sehingga } \\
\text { menggeser proses } \\
\text { makan } \\
\text { mengkonsumsi } \\
\text { beberapa jenis } \\
\text { kuliner Betawi } \\
\text { Familiar }\end{array}$ & $\begin{array}{l}\text { a) Menjadikan keaslian alat } \\
\text { masak dan alat saji } \\
\text { sebagai nilai tambah } \\
\text { dalam layanan kuliner } \\
\text { b) Penguatan jjaringan } \\
\text { pada pengusaha dan } \\
\text { pengrajin alat masak dan } \\
\text { alat saji tradisional } \\
\text { c) Mensosialisasikan dan } \\
\text { mngenalkan variasi } \\
\text { kuliner dan nilai } \\
\text { budayanya kepada } \\
\text { generasi muda }\end{array}$ & $\begin{array}{l}\text { a) Meningkatkan publikasi } \\
\text { kuliner Betawi } \\
\text { b) Rekyasa produksi } \\
\text { produk kuliner agar } \\
\text { dapat dipasarkan lintas } \\
\text { waktu dan lintas lokasi }\end{array}$ \\
\hline Tantangan & ST & WT \\
\hline $\begin{array}{l}\text { 3. Kurangnya } \\
\text { pemahaman nilai } \\
\text { budaya Kuliner } \\
\text { Betawi sehingga } \\
\text { beberapa kuliner } \\
\text { Betawi Familiar } \\
\text { tidak disajikan sesuai } \\
\text { dengan } \\
\text { peruntukannya } \\
\text { 4. Kurangnya minat } \\
\text { masyarakat dalam } \\
\text { pengolahan kuliner } \\
\text { Tradisional Betawi } \\
\text { 5. Lemahnya } \\
\text { koordinasi lintas } \\
\text { sektoral }\end{array}$ & & \\
\hline
\end{tabular}

Sumber: Pengolahan data penelitian 2017

Terdapat 13 macam operasional strategis yang dapat dilakukan untuk meningkatkan nilai Kuliner Betawi Familiar agar eksistensinya tetap dapat dipertahankannya. Ke-13 operasional strategis tersebut terklasifikasi dalam tiga kategori 
(sesuai rekomendasi pada hasil grand matriks), yaitu Product and market development, Market penetration dan Backward and forward integration. Terdapat 7 operasionalisasi strategi sebagai implementasi klasifikasi startegi yang pertama (Product and market developmen). Oprasional strategis tersebut adalah: Reorientasi produksi makanan, dari makanan rumahan menuju produksi makanan yang memiliki nilai ekonomis, sosialisasi nilai soaial budaya kuliner agar pengembangan kuliner yang ada mengarah ke peningkatan pengetahuan kuliner, menjadikan keaslian alat masak dan alat saji sebagai nilai tambah dalam layanan kuliner, mensosialisasikan dan mngenalkan variasi kuliner dan nilai budayanya kepada generasi muda, mengembangan promosi WOM, mengembangkan pasar kuliner pada wilayah sekitar DKI Jakarta, meningkatkan publikasi kuliner Betawi, merekayasa produksi produk kuliner agar dapat dipasarkan lintas waktu dan lintas lokasi.

Terdapat 3 operasional strategis pada kategori strategi kedua (Market penetration), yaitu: Fokus pada pengembangan kuliner familliar menjadikan ke enam kuliner tersebut sebagai icon, sosialiasi proses produksi yang bertanggungjawab, mengadakan pelatihan untuk meningkatkan kemampuan produksi kuliner. Dan terdapat tiga oprasional strategis pada kategori strategi ke tiga (Backward and forward integration) yaitu: Pengembangan cluster produsen dan cluster pemasar kuliner, memperkuat pengadaan sumber bahan kuliner untuk menjaga eksistensi kuliner Betawi, penguatan terhadap pengusaha dan pengrajin alat masak dan alat saji tradisional.

\section{Model Strategi Pengembangan Kuliner Recall.}

Hasil studi pada tahap kedua menghasilkan data bahwa terdapat 91 jenis kuliner tradisional Betawi yang saat ini masuk dalam kategori recall. Selain beberapa jenis kuliner rumahan, mayoritas jenis kuliner yang masuk dalam kategori recall ini adalah kuliner selingan yang dalam perkembangannya telah menjadi komuditas industri dan banyak melibatkan UMKM didalamnya baik sebagai pengrajin maupun pemasar. Hanya saja dalam perkembangannya pendistribusian jenis kuliner tersebut kurang merata sehingga sangat mempengaruhi pengetahuan masyarakat terhadap jenis kuliner tersebut, bahkan pada hasil studi menunjukkan bahwa terdapat perbedaan pengetahuan antar masyarakat non Betawi di kelima wilayah DKI Jakarta. Ini disebabkan oleh kurang meratanya pendistribusian kuliner kepada masyarakat baik terkait jumlah kuliner yang dijual per penjual dan kurangnya meratanya distribusi penjual disetiap wilayah di DKI Jakarta. Table 4 merupakan pemetaan matrik EFAS IFAS dari kuliner Betawi Recall.

Tabel 4

EFAS/ IFAS Kuliner Recall

\begin{tabular}{lccc}
\hline Internal Faktor & Bobot & Rank & Total \\
\hline Kekuatan & & 3 & 0,33 \\
\hline $\begin{array}{l}\text { 1. } 4 \text { diantara ke-91 kuliner Betawi Recall telah } \\
\text { masuk sebagai icon kuliner Unggulan }\end{array}$ & 0,11 & & \\
$\begin{array}{l}\text { Indonesia } \\
\text { 2. Bahan baku ke-91 kuliner Betawi Recall } \\
\text { mudah didapatkan }\end{array}$ & 0,23 & 4 & 0,92 \\
3. Ke-91 kuliner Betawi Recall adalah kuliner \\
halal
\end{tabular}


Lanjutan Tabel 4

4. Sebagian besar bahan baku dari ke-91
kuliner Betawi Recall tidak mengenal
$\begin{aligned} & \text { musim } \\ & \text { Sebagian besar kuliner Betawi Recall }\end{aligned}$

\begin{tabular}{|c|c|c|c|}
\hline Sub Total & 1,0 & & 2,83 \\
\hline \multicolumn{4}{|l|}{ Kelemahan } \\
\hline $\begin{array}{l}\text { 1. Kurangnya publikasi khusus Kuliner } \\
\text { Betawi }\end{array}$ & 0,11 & 2 & 0,22 \\
\hline $\begin{array}{l}\text { 2. Promosi khusus kuliner Betawi kurang } \\
\text { intensif }\end{array}$ & 0,2 & 3 & 0,6 \\
\hline $\begin{array}{l}\text { 3. Kualitas penyedia kuliner Betawi Recall } \\
\text { masih kurang baik }\end{array}$ & 0,12 & 4 & 0,48 \\
\hline $\begin{array}{l}\text { 4. Pemasaran ke }-91 \text { produk kuliner Betawi } \\
\text { Recall yang masih sangat tradisional }\end{array}$ & 0,15 & 4 & 0,6 \\
\hline $\begin{array}{l}\text { 5. Tata kelola produksi ke }-91 \text { kuliner Betawi } \\
\text { Recall belum terstandarisasi }\end{array}$ & 0,11 & 4 & 0,44 \\
\hline $\begin{array}{l}\text { 6. Pengemasan ke-91 kuliner Betawi Recall } \\
\text { sangat standar }\end{array}$ & 0,09 & 3 & 0,27 \\
\hline $\begin{array}{l}\text { 7. Beberapa kuliner Betawi Recall sudah } \\
\text { banyak mengalami modifikasi dalam alat } \\
\text { memasak dan penyajian }\end{array}$ & 0,05 & 2 & 0,1 \\
\hline $\begin{array}{l}\text { 8. Belum maksimalnya teknologi dalam } \\
\text { rekayasa produksi }\end{array}$ & 0,1 & 2 & 0,2 \\
\hline $\begin{array}{l}\text { 9. Kurangnya kemampuan tata kelola } \\
\text { keuangan pada pengusaha } \\
\text { Kuliner }\end{array}$ & 0,07 & 2 & 0,14 \\
\hline Sub Total & 1 & & 3,05 \\
\hline \multicolumn{4}{|l|}{ Eksternal Faktor } \\
\hline Peluang & Bobot & Rank & Total \\
\hline $\begin{array}{l}\text { 1. Banyak jenis kuliner Betawi Recall yang } \\
\text { masih disajikan pada kegiatan kemasya- } \\
\text { rakatan }\end{array}$ & 0,31 & 4 & 1,24 \\
\hline $\begin{array}{l}\text { 2. Trand kuliner Tradisional sedang banyak } \\
\text { diangkat oleh media }\end{array}$ & 0,19 & 3 & 0,57 \\
\hline $\begin{array}{l}\text { 3. Besarnya perhatian akademisi terhadap } \\
\text { pengembangan UMKM kuliner }\end{array}$ & 0,23 & 2 & 0,46 \\
\hline $\begin{array}{l}\text { 4. Besarnya perhatian pemerintah pada } \\
\text { penguaha UMKM kuliner, dimana } \\
\text { mayoritas dari ke-91 jenis kuliner Recall } \\
\text { adalah hasil industri }\end{array}$ & 0,17 & 2 & 0,34 \\
\hline $\begin{array}{l}\text { 5. Diaspora masyarakat Betawi di wilayah } \\
\text { sekitar DKI Jakarta }\end{array}$ & 0,1 & 2 & 0,2 \\
\hline Sub Total & 1 & & 2,81 \\
\hline \multicolumn{4}{|l|}{ Eksternal Faktor } \\
\hline Tantangan & Bobot & Rank & Total \\
\hline
\end{tabular}


Lanjutan Tabel 4

\begin{tabular}{llcc}
\hline \hline 1. Belum adanya target pasar yang spesifik & 0,18 & 4 & 0,72 \\
2. Sulit untuk mendapat supplier yang & 0,22 & 4 & 0,88 \\
konsisten sehingga dapat menjaga eksis- \\
$\begin{array}{l}\text { tensi produksi kuliner Betawi } \\
\text { 3egulasi yang mempersulit perijinan }\end{array}$ & 0,27 & 3 & 0,81 \\
pengusaha Kuliner & & & \\
$\begin{array}{l}\text { 4. Regulasi pengucuran kredit bagi UMKM } \\
\text { 5. Kurangnya minat masyarakat dalam } \\
\text { pengolahan kuliner Tradisional Betawi }\end{array}$ & 0,15 & 2 & 0,3 \\
\hline Sub Total & $\mathbf{1}$ & 4 & 0,72 \\
\hline
\end{tabular}

Sumber: pengolahan data penelitian 2017, pemberian bobot merujuk pada proses compareing system yang mengadopsi konsep AHP (Analisis Hirarki Proses)

Matrik EFAS IFAS Kuliner Recall terlihat bahwa faktor eksternal memiliki total score yang lebih tinggi (peluang 2,81 dan hambatan 3,43), sedangkan variabel-variabel pada faktor internal (kekuatan 2,83 dan kelemahan 3,05). Hal ini menunjukkan bahwa posisioning Kuliner Betawi Recall kurang kuat dan masih banyk dipengaruhi oleh faktor eksternal. Sebagai bahan penyusunan oprasional strategis, gambar 29 merupakan grand matriks kuliner Betawi Recall sebagai usaha memetakan posisioning strategi kuliner Betawi Recall.
Pada posioning kuliner Betawi Recall yang berada di kuadran 3, strategi yang paling realistis untuk dikembangkan adalah strategi defensive.

Persaingan pasar kuliner yang sangat ketat menuntut pengusaha dan pengrajin kuliner untuk dapat mengolah pasar yang sudah terbentuk secara optimal. Berdasarkan key faktor yang didapatkan, berikutnya adalah membuat oprasional strategis untuk menformulasikan strategi yang dapat dilakanakan untuk menjaga pasar kuliner Betawi Recall.

\section{Tabel 5}

\section{Matrik SWOT Kuliner Recall}

\begin{tabular}{ll}
\hline \hline \multicolumn{1}{c}{ Kekuatan } & \multicolumn{1}{c}{ Kelemahan } \\
\cline { 2 - 3 } 1. 4 diantara ke-91 kuliner & 1. Kurangnya publikasi \\
Betawi recall telah & khusus Kuliner Betawi \\
masuk sebagai icon & 2. Promosi khusus kuliner \\
kuliner Unggulan & Betawi kurang intensif \\
Indonesia & 3. Kualitas penyedia kuliner \\
2. Bahan baku ke-91 & Betawi Recall masih kurang \\
kuliner Betawi Recall & baik \\
mudah didapatkan & 4. Pemasaran ke -91 produk \\
3e-91 kuliner Betawi & kuliner Betawi Recall yang \\
Recall adalah kuliner & masih sangat tradisional \\
halal & 5. Tata kelola produksi ke - \\
4. Sebagian besar bahan & 91 kuliner Betawi Recall \\
baku dari ke-91 kuliner & belum terstandarisasi \\
Betawi Recall tidak & 6. Pengemasan ke-91 kuliner \\
mengenal musim & Betawi Recall sangat \\
& standar \\
\hline
\end{tabular}


5. Sebagian besar kuliner Betawi Recall merupakan kuliner rumahan

7. Beberapa kuliner Betawi Recall sudah banyak mengalami modifikasi dalam alat memasak dan penyajian

8. Belum maksimalnya teknologi dalam rekayasa produksi

9. Kurangnya kemampuan tata kelola keuangan pada pengusaha kuliner

\section{Peluang}

1. Banyak jenis kuliner Betawi Recall yang masih disajikan pada kegiatan kemasyarakatan

2. Trand kuliner Tradisional sedang banyak diangkat oleh media

3. Besarnya perhatian pemerintah pada penguaha UMKM kuliner (secara umum), dimana mayoritas dari ke91 jenis kuliner Recall adalah hasil industri

4. Besarnya perhatian akademisi terhadap pengembangan UMKM kuliner

5. Diaspora masyarakat Betawi di wilayah sekitar DKI Jakarta

\section{Tantangan}

1. Belum adanya target pasar yang spesifik

2. Sulit untuk mendapat supplier yang konsisten sehingga dapat menjaga eksistensi

\section{SO}

a) Melakukan perbaikan sistem oprasional produsi kuliner

b) Mengoptimlakan penggunaan sarana dan prasarana produksi kuliner

c) Memperbaiki sistem layanan penjualan kuliner

d) Bekerjasama dengan catering dan hotel untuk memperbanyak variasi kuliner Betawi dalam menu yang ditawarkan

e) Menfokuskan kegiatan abdimas pada penguatan UMKM kuliner Betawi dalam menghadapi persaingan pasar global

f) Menjadikan Kuliner Betawi sebagai Icon Kuliner Jabodetabek

WO

a) Memilih sebagain kuliner Betawi Recall sebagai icon kuliner Betawi (dan dilakukan secara bergantian)

b) Memaksimalkan penggunaan media advertising dalam mempublikasi Kuliner

c) Sosialiasi proses produksi yang bertanggungjawab

d) Mengadakan pelatihan untuk meningkatkan kemampuan dan penegathuan dalam meproduksi kuliner

\section{ST}

a) Fokus pada pasar yang sudah terbentuk dengan target menengah kebawah

b) Memperkuat kemitraan pada retailer Kuliner Betawi Recall

c) Merekonstruksi arah regulasi perijianan

\section{WT}

a) Memodivikasi sistem distribusi kuliner dengan sistem delevary (lebih modern)

b) Modifikasi peralatan memasak; Penggunaan bricket sebagai pengganti arang dalam proses memasak 


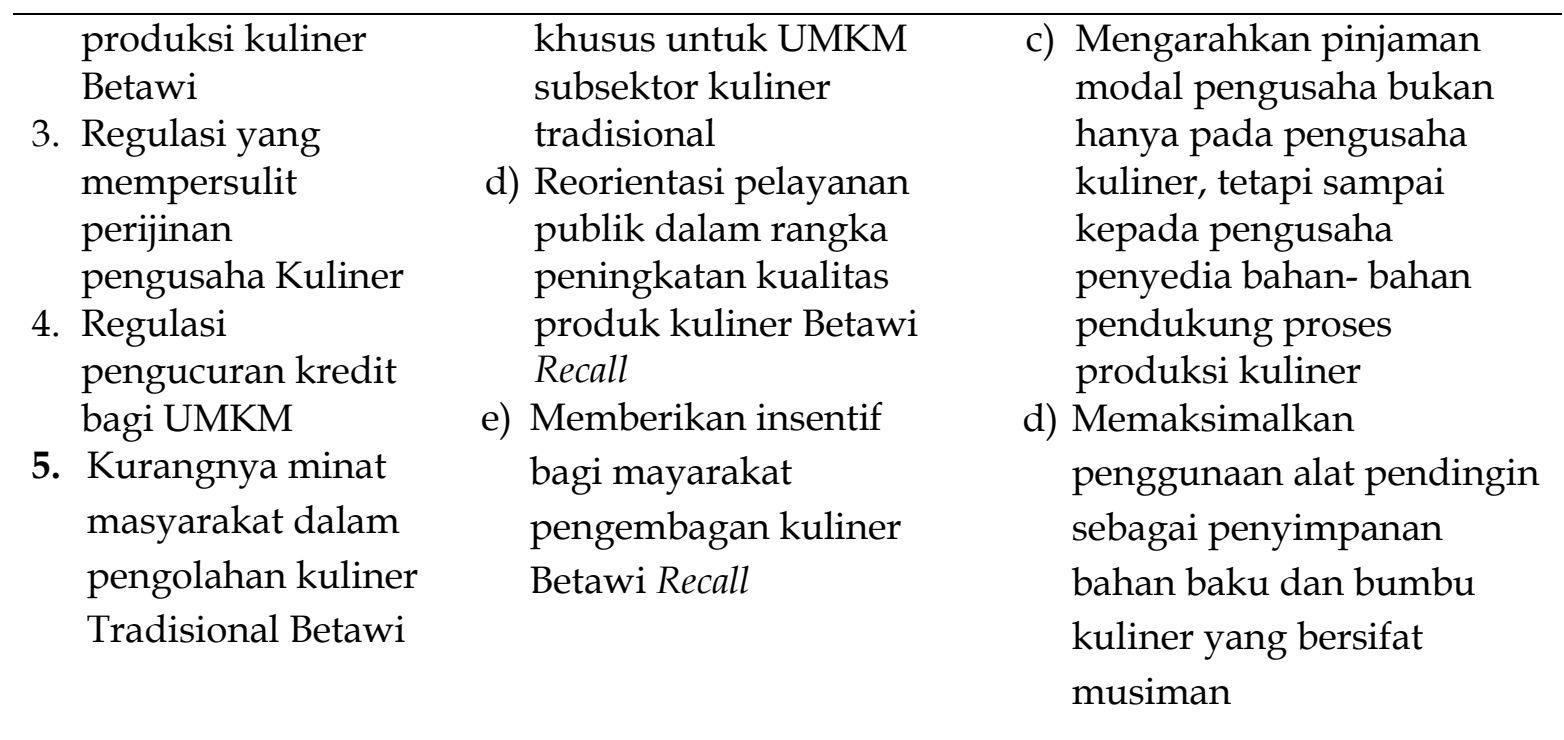

Sumber : Pengolahan data penelitian 2017

Berdasarkan hasil formulasi strategi yang mengelaburasi semua key factor baik kekuatan, kelemahan, peluang dan tantangan yang dihadapi dalam mengembangan produk kuliner recall, maka terdapat 18 oprasional strategis yang dapat diimplementasikan untuk menjaga eksistensi kuliner recall dan mengangkatnya untuk menjadi lebih populer. Ke-18 oprasional strategis terebut adalah: Melakukan perbaikan sistem oprasional produsi kuliner, mengoptimalkan penggunaan sarana dan prasarana produksi kuliner, memperbaiki sistem layanan penjualan kuliner, bekerjasama dengan catering dan hotel untuk memperbanyak variasi kuliner Betawi dalam menu yang ditawarkan, menfokuskan kegiatan abdimas pada penguatan UMKM kuliner Betawi dalam mengadapi persaingan pasar global, memilih sebagain kuliner Betawi Recall sebagai icon kuliner Betawi (dan dilakukan secara bergantian), memaksimalkan penggunaan media advertising dalam mempublikasi Kuliner, sosialiasi proses produksi yang bertanggungjawab, mengadakan pelatihan untuk meningkatkan kemampuan dan pengetahuan dalam meproduksi kuliner, fokus pada pasar yang sudah terbentuk dengan target menengah kebawah, memperkuat kemitraan pada retailer Kuliner Betawi Recall, merekonstruksi arah regulasi pengajuan perujianan khusus untuk UMKM sub sektor kuliner tradisional, reorientasi pelayanan publik dalam rangka peningkatan kualitas produk kuliner Betawi Recall, memberikan insentif bagi masyrakat pengembangan kuliner Betawi Recall, memodivikasi sistem distribusi kuliner dengan sistem delevery (lebih modern), modifikasi peralatan memasak; Penggunaan bricket sebagai pengganti arang dalam proses memasak, mengarahkan pinjaman modal pengusaha bukan hanya pada pengusaha kuliner

\section{Model Strategi Pengembangan Kuliner Pastknown.}

Kuliner pastknown merupakan kuliner yang saat ini sudah tidak dikenal lagi oleh masyarakat secara umum. Kuliner jenis ini sudah hilang baik dikegiatan kemasyarakatan maupun pada pasar kuliner secara global. Berdasarkan hasil studi, terdapat 16 jenis kuliner dalam kategori pastknown, dan mayoritas kuliner dalam kategori ini adalah kuliner yang dahulu sering digunakan pada seremonial tertentu baik seremonial adat maupun keagamaan. Pada perkembangannya, moderenisasi berdampak juga pada pergeseran nilai-nilai budaya kuliner pada Masyarakat Betawi dimana saat ini variasi kuliner sudah jarang disajikan dalam mengiringi prosesi-prosesi adat dan keagamaan 
Masyarakat Betawi. Selain itu, kuliner pada acara-acara keragamaan lebih bersifat modern dan homogen, maka jenis kuliner tersebut mulai ditinggalkan. Strategi mengembangkan kuliner pastknown bertujuan untuk mengembalikan eksistensi dan popularitas Kuliner Betawi khususnya pada prosesi sosial keagaaman sehingga nilai yang terkandung dalam Budaya Kuliner Betawi dapat terus dipertahankan dan dikomunikasikan dari generasi ke generasi selanjutnya.

Table 6 merupakan formulasi matrik IFAS/EFAS dari kuliner pastknown.

Tabel 6

Formulasi Matrik IFAS/EFAS Kuliner Pastknown

\begin{tabular}{lccc}
\hline \hline Internal Faktor & Bobot & Rank & Total \\
\hline Kekuatan & & 4 & 1,08 \\
\hline $\begin{array}{l}\text { 1. Kuliner Betawi Pastknown mayoritas adalah } \\
\text { kuliner yang memiliki nilai soial budaya yang } \\
\text { tinggi }\end{array}$ & 0,27 & 2 & 0,64 \\
$\begin{array}{l}\text { 2. Sebagian kuliner Betawi Pastknown adalah } \\
\text { jenis kuliner rumahan }\end{array}$ & 0,32 & 1 & 0,22 \\
$\begin{array}{l}\text { 3. Bahan baku ke-16 kuliner Betawi Pastknown } \\
\text { mudah didapatkan }\end{array}$ & 0,22 & 2 & 0,38 \\
$\begin{array}{l}\text { 4. Ke-16 kuliner Betawi Pastknown adalah kuliner } \\
\text { halal }\end{array}$ & 0,19 & &
\end{tabular}

\begin{tabular}{lccc}
\hline Sub Total & $\mathbf{1}$ & & $\mathbf{2 , 3 2}$ \\
\hline Kelemahan & & 3 & 0,48 \\
\hline $\begin{array}{l}\text { 1. Jumlah kuliner Pastknown cukup banyak (jika } \\
\text { dibandingkan dengan jumlah kuliner familiar) }\end{array}$ & 0,16 & 4 & 0,92 \\
$\begin{array}{l}\text { 2. Sulitnya menemukan bahan baku ke-16 } \\
\text { kuliner Betawi Pastknown }\end{array}$ & 0,23 & 3 & 0,72 \\
$\begin{array}{l}\text { 3. Mayoritas bumbu kuliner Betawi Pastknown } \\
\text { sudah dimodifikasi }\end{array}$ & 0,24 & 2 & 0,36 \\
$\begin{array}{l}\text { 4. Mayoritas alat masak dan penyajian kuliner } \\
\text { Betawi Pastknown sudah mengalami } \\
\text { perubahan }\end{array}$ & 0,18 & & \\
$\begin{array}{l}\text { 5. Belum maksimalnya teknologi dalam rekayasa } \\
\text { produksi }\end{array}$ & 0,19 & 2 & 0,38 \\
\hline
\end{tabular}

\begin{tabular}{lccc}
\hline Sub Total & $\mathbf{1}$ & $\mathbf{2 , 8 6}$ \\
\hline \multicolumn{5}{c}{ Eksternal Faktor } \\
\hline $\begin{array}{l}\text { Peluang } \\
\text { Trand kuliner Tradisional sedang banyak } \\
\text { diangkat oleh media }\end{array}$ & 0,17 & 0,51 \\
$\begin{array}{l}\text { 2. Berkembangnya para gourmands (pencinta } \\
\text { makanan dengan cita rasa khas) yang } \\
\text { menjadikan eksporasi rasa makanan menjadi } \\
\text { motivasi utama dalam mengkonsumsi kuliner }\end{array}$ & & 2,19 & 0,38 \\
3. Fakta bahwa kuliner tradisional memiliki nilai & 0,21 & 2 & 0,42
\end{tabular}
kenangan yang sulit terganti oleh makanan fussion maupun makanan modern lainny 
4. Tersedianya dasar hukum sebagai landasan 0,14 1

0,14 operasionalbaik berupa perundang-undangan maupun peraturan daerah

5. Berkembangnya para gourmands yang menjadikan eksporasi rasa makanan menjadi motivasi utama dalam mengkonsumsi kuliner

6. Fakta bahwa kuliner tradisional memiliki nilai kenanganan yang sulit terganti oleh makanan fussion maupun makanan modern lainnya

\begin{tabular}{|c|c|c|c|}
\hline Sub Total & 1 & & 1,87 \\
\hline \multicolumn{4}{|c|}{ Eksternal Faktor } \\
\hline Tantangan & Bobot & Rank & Total \\
\hline $\begin{array}{l}\text { 1. Kurangnya perhatian pemerintah untuk } \\
\text { mensosialisasi ke-16 jenis kuliner Pastknown }\end{array}$ & 0,09 & 4 & 0,36 \\
\hline $\begin{array}{l}\text { 2. Kurangnya maksimalnya peranan budayawan } \\
\text { dan akademisi dalam mensosialisasi nilai } \\
\text { sosial budaya ke-16 jenis kuliner Pastknown }\end{array}$ & 0,16 & 2 & 0,32 \\
\hline $\begin{array}{l}\text { 3. Kurangnya publikasi kuliner Betawi Pastknown } \\
\text { dengan mengutamakan nilai dan fungsi sosial } \\
\text { budayanya }\end{array}$ & 0,24 & 3 & 0,72 \\
\hline $\begin{array}{l}\text { 4. Kurangnya deseminasi ke-16 jenis kuliner } \\
\text { Pastknown antar generasi }\end{array}$ & 0,21 & 4 & 0,84 \\
\hline 5. Kurangnya koordinasi antar stakeholder & 0,19 & 1 & 0,19 \\
\hline $\begin{array}{l}\text { 6. Kurangnya minat masyarakat dalam } \\
\text { pengolahan kuliner Tradisional Betawi }\end{array}$ & 0,11 & 2 & 0,22 \\
\hline Sub Total & 1 & & 2,65 \\
\hline
\end{tabular}

Sumber: Pengolahan data penelitian 2017, pemberian bobot merujuk pada proses compareing system yang mengadopsi konsep AHP (Analisis Hirarki Proses)

Matrik EFAS IFAS Kuliner Pastknown menunjukkan bahwa faktor internal (kekuatan 2,32 dan kelemahan 2,86), sedangkan variabel-variabel pada faktor eksternal memiliki total score yang lebih tinggi (peluang 1,87 dan hambatan 2,65). Posisioning kuliner Betawi Pastknown dapat dikatakan sangat lemah dimana scor kelemahan mendominasi pada faktor internal dan hambatan mendominasi pada faktor eksternal. Sebagai bahan penyusunan oprasional strategis, gambar 30 merupakan grand matriks kuliner Betawi Pastknown sebagai usaha memetakan posisioning strategi dan oprasionaliasi strategis.

Grand matrik kuliner Pastknown menunjukkan bahwa posisioning kuliner Betawi dalam kategori Pastknown saat ini berada pada strategi expention, artinya perlu sebuah rekayasa pemasaran baik dalam hal produk dan layanan serta dalam hal expansi pasar. Strategi yang realistis untuk dilakukan adalah penetrasi pasar, ekspansi pasar dan perbaikan proses produksi dan layanan. Tabel 7 berikut adalah matrik SWOT yang akan mengiintegrasikan kekuatan, kelemahan, peluang dan tantangan untuk mengarahkan arah oprasional strategik yang dapat dilakukan.

Formulasi strategi pada Matrik SWOT menghasilkan 14 oprasional strategis yang terintergrasi dengan hasil pada garnd matriks. Ke-14 oprasional strategis terebut adalah: Bekerjasama dengan catering dan hotel untuk memperbanyak variasi kuliner Betawi dalam menu yang ditawarkan, mengarahkan produksi makanan, dari makanan rumahan menuju produksi makan- 
an yang memiliki nilai ekonomis, sosialisasi nilai soaial budaya kuliner agar pengembangan kuliner yang ada mengarah ke pe- ningkatan pengetahuan kuliner, pengembangan cluster produsen dan cluster pemasar kuliner.

Table 7

Matriks SWOT Kuliner Pastknown

\begin{tabular}{|c|c|c|}
\hline & Kekuatan & $\begin{array}{l}\text { Kelemahan } \\
\end{array}$ \\
\hline & $\begin{array}{l}\text { 1. Kuliner Betawi Past- } \\
\text { known mayoritas adalah } \\
\text { kuliner yang memiliki } \\
\text { nilai sosial budaya yang } \\
\text { tinggi } \\
\text { 2. Sebagian kuliner Betawi } \\
\text { Pastknown adalah jenis } \\
\text { kuliner rumahan } \\
\text { 3. Bahan baku ke-16 } \\
\text { kuliner Betawi } \\
\text { Pastknown mudah } \\
\text { didapatkan } \\
\text { 4. Ke-16 kuliner Betawi } \\
\text { Pastknown adalah } \\
\text { kuliner halal }\end{array}$ & $\begin{array}{l}\text { 1. Jumlah kuliner Past- } \\
\text { known cukup banyak } \\
\text { (jika dibandingkan } \\
\text { dengan jumlah kuliner } \\
\text { familiar) } \\
\text { 2. Sulitnya menemukan } \\
\text { bahan baku ke-16 kuli- } \\
\text { ner Betawi Pastknown } \\
\text { 3. Mayoritas bumbu } \\
\text { kuliner Betawi Past- } \\
\text { known sudah dimodi- } \\
\text { fikasi } \\
\text { 4. Mayoritas alat masak } \\
\text { dan penyajian kuliner } \\
\text { Betawi Pastknown } \\
\text { sudah mengalami } \\
\text { perubahan } \\
\text { 5. Belum maksimalnya } \\
\text { teknologi dalam } \\
\text { rekayasa produksi } \\
\text { 6. Belum maksimalnya } \\
\text { teknologi dalam } \\
\text { rekayasa produksi }\end{array}$ \\
\hline Peluang & SO & WO \\
\hline $\begin{array}{l}\text { 1. Trand kuliner Tradisi- } \\
\text { onal sedang banyak } \\
\text { diangkat oleh media } \\
\text { 2. Berkembangnya para } \\
\text { gourmands (pencinta } \\
\text { makanan dengan cita } \\
\text { rasa khas) yang men- } \\
\text { jadikan eksporasi rasa } \\
\text { makanan menjadi } \\
\text { motivasi utama dalam } \\
\text { mengkonsumsi kuliner } \\
\text { 3. Fakta bahwa kuliner } \\
\text { tradisional memiliki } \\
\text { nilai kenangan yang } \\
\text { sulit terganti oleh } \\
\text { makanan fussion }\end{array}$ & $\begin{array}{l}\text { a) Bekerjasama dengan } \\
\text { catering dan hotel untuk } \\
\text { memperbanyak variasi } \\
\text { kuliner Betawi dalam } \\
\text { menu yang ditawarkan } \\
\text { b) Merubah pola produksi } \\
\text { makanan, dari makanan } \\
\text { rumahan menuju } \\
\text { produksi makanan yang } \\
\text { memiliki nilai ekonomis } \\
\text { c) Sosialisasi nilai soaial } \\
\text { budaya kuliner agar } \\
\text { pengembangan kuliner } \\
\text { yang ada mengarah ke } \\
\text { peningkatan } \\
\text { pengetahuan kuliner }\end{array}$ & $\begin{array}{l}\text { a) Sosialiasi proses pro- } \\
\text { duksi yang bertang } \\
\text { gungjawab } \\
\text { b) Mengadakan pelatihan } \\
\text { untuk meningkatkan } \\
\text { kemampuan dan } \\
\text { penegathuan dalam } \\
\text { meproduksi kuliner } \\
\text { c) Rekyasa produksi } \\
\text { produk kuliner agar } \\
\text { dapat dipasarkan lintas } \\
\text { waktu dan lintas lokasi }\end{array}$ \\
\hline
\end{tabular}


maupun makanan

modern lainnya.

4. Tersedianya dasar hukum sebagai landasan operasional baik berupa perundangundangan maupun peraturan daerah

5. Berkembangnya para gourmands (pencinta makanan dengan cita rasa khas) yang menjadikan eksporasi rasa makanan menjadi motivasi utama dalam mengkonsumsi kuliner

6. Fakta bahwa kuliner tradisional memiliki nilai kenanganan yang sulit terganti oleh makanan fussion maupun makanan modern lainnya
1. Kurangnya perhatian pemerintah untuk mensosialisasi ke-16 jenis kuliner Pastknown

2. Kurangnya maksimalnya peranan budayawan dan akademisi dalam mensosialisasi nilai sosial budaya ke-16 jenis kuliner Pastknown

3. Kurangnya deseminasi ke-16 jenis kuliner Pastknown antar generasi

4. Kurangnya publikasi kuliner Betawi Pastknown dengan mengutamakan nilai dan fungsi sosial budayanya

5. Kurangnya koordinasi antar stakehoder d) Pengembangan cluster produsen dan cluster pemasar kuliner Memperkuat pengadaan sumber bahan kuliner untuk menjaga eksistensi kuliner Betawi

\section{ST}

a) Fokus pada pasar yang sudah terbentuk dengan target menengah kebawah

b) Memperkuat kemitraan pada retailer Kuliner Betawi

c) Memberikan insentif bagi mayarakat pengembagan kuliner Betawi

d) Menfokuskan kegiatan abdimas pada penguatan UMKM kuliner Betawi dalam mengadapi persaingan pasar global a) Modifikasi peralatan memasak; Penggunaan bricket sebagai pengganti arang dalam proses memasak

b) Memaksimalkan penggunaan alat pendingin sebagai penyimpanan bahan baku dan bumbu kuliner yang bersifat musiman

c) Meningkatkan publikasi kuliner Betawi 
6. Kurangnya minat masyarakat dalam pengolahan kuliner Tradisional Betawi

Sumber; Pengolahan data penelitian 2017

Memperkuat pengadaan sumber bahan kuliner untuk menjaga eksistensi kuliner Betawi, Sosialiasi proses produksi yang bertanggungjawab, mengadakan pelatihan untuk meningkatkan kemampuan dan pengetahuan dalam meproduksi kuliner, rekyasa produksi produk kuliner agar dapat dipasarkan lintas waktu dan lintas lokasi, fokus pada pasar yang sudah terbentuk dengan target menengah kebawah, memperkuat kemitraan pada retailer Kuliner Betawi Recall, memberikan insentif bagi masyrakat pengembangan kuliner Betawi Pastknown, menfokuskan kegiatan abdimas pada penguatan UMKM kuliner Betawi dalam mengadapi persaingan pasar global.

\section{SIMPULAN DAN SARAN Simpulan}

Pengembangan Kuliner yang dikemas saat ini kurang mengedepankan potensi Kuliner Betawi, sehingga nuansa kelokalan Betawi kurang dapat dirasakan oleh wisatawan. Memunculkan khasanah budaya lokal menjadi penting untuk mengembalikan kearifan budaya dalam komunitas urban. Perlu untuk diingatkan kembali bahwa Budaya Betawi merupakan embrio dari budaya di Jakarta dan perkembangan sosial budaya masyarakat saat ini, Budaya lokal Betawi mulai ditinggalkan

Terkait dengan pemasaran, saat ini strategi pemasaran yang dikembangkan masih sangat parsial, kurang adanya koordinasi antara strakeloder. Sehingga pemasaran kuliner makin terbawa oleh arus permintaan pasar, yang menyebabkan banyak hilangnya variasi kuliner Tradisional. Selain itu masyarakat juga memegang peranan penting baik ebagai produsen maupun konsumen Kuliner Betawi.

\section{Saran}

Beberapa saran yang dapat diberikan penulis, bahwa perlu sebuah koordinasi lintas stakeholder baik pemerintah, masyarakat, budayawan dan pengusaha. Hal ini perlu dilakukan agar tidak terjadi overlay kepentingan dan perbedaan pola dalam mengoptimalisasikan strategi, yang sering kali menjadi hambatan satu sama lain. Kemudian yang tidak kalah pentingnya adalah perlunya mengimplementasikan strategi pemasaran, membangun produk hingga menditribusiakan produk bahkan sampai mengusahakan terjadinya repeat order dari konsumen mengingaat saat ini pasar sudah terbentuk hanya saja masih dalam taraf besarnya kuantitas. Dan sebagai arah berikutnya adalah meningkatakan kualitas dari pemasaran Kuliner Tradisional Betawi dengan meningkatkan nilai dari produk Kuliner Betawi, sehingga Kuliner Betawi tidak lagi dikenal sebagai street food atau kuliner yang relatif murah, tetapi Kuliner Betawi menjadi salah satu produk premium.

\section{DAFTAR PUSTAKA}

Avenzora, R., D. Darusman, J. Prihatno, dan D. T. Untari. 2014. The Business Potentials of Betawi Traditional Culinary on Traditional Culinary Ecotourism Market in the DKI Jakarta. Prosiding International Seminar of Tourism Bandung: 516-523.

Boyd, W. H., O. C. Walker, dan J. C. Larreche. 2000. Manajemen Pemasaran: Suatu Pendekatan Strategisdengan Orientasi Global. Erlangga.Jakarta.

David, F. 2005.Manajemen Strategik. Salemba Empat. Jakarta.

Jones, M. B., J. Finnan, T. R. Hodkinson. 2015. Morphological and Physiological Traits for Higher Biomass Production in Perennial Rhizomatous Grasses Grown on Marginal Land. GCB Bioenergy 7(2): 375-385. 
Kastaman, R. 2003. Kajian Teknis Budidaya dan Manajeman Produksi Pengolahan Minyak Nilam di Beberapa Sentra Nilam Jawa Barat. Laporan Kegiatan Pengabdian Masyarakat Universitas Padjadjaran. Bandung.

Krisnansari, D. 2010. Nutrisi dan Gizi Buruk. Mandala of Health 4(1): 9-21.

Maberly, C. dan D. Reid. 2014. Gastronomy: an Approach to Study Food. Nutrition and Food Science 44(4): 272-278.

Mufidah, N. L. 2012. Pola Konsumsi Masyarakat Perkotaan (Studi Deskriptif Pemanfaatan Foodcourt). BioKultur 1(2): 157-178.

Ongkorahardjo, E. P. 2015. Formulasi Strategi Usaha Makanan Ringan Tradisional Ny. Gan Di Surabaya. Jurnal Agora 3(2): 665- 675.

O'Callaghan, C., C. D. Feliciantonio, dan M. Byrne. 2017. Governing Urban Vacancy in Post-Crash Dublin: Contested Property and Alternative Social Projects. Urban Geography 39(6): 868-891.

Parys, N. 2013. Cooking up a Culinary Identity for Belgium. Gastrolinguistics in Two Belgian Cookbooks (19th century). Appetite 71: 218-231.

Pisman, A., G. Allaert, dan P. Lombaerde. 2011. Urban and Suburban Lifestyles and Residential Preferences in a Highly Urbanized Society: Experiences from a Case Study in Ghent (Flanders, Belgium). Urban Studies in Belgium 1(2): 1-16.

Parami, J. 2006. Intercultural Jakarta, Ambience of Betawi Theatre to Indonesian Theatre. Wacana Seni Journal (Arls Discourse) 5(1): 43-69.

Perry, M., C. Rosenzweig, A. Iglesias, M. Livermore, dan G. Fischer. 2004. Effects of Climate Changeon Global Food Production under SRES Emissionsand Socio-Economic Scenarios. Elsevire Global Envirinmental Change 14: 53-67.
Rais, S. A. 2004. Eksplorasi Plasma Nutfah Tanaman Pangan di Provinsi Kalimantan Barat. Buletin Plasma Nutfah 10(1): 29-42.

Sabudi, I. N. S. 2011. Klasifikasi Makanan Tradisional Bali di Perhotelan.Jurnal Kepariwisataan Indonesia 10(2): 33-57.

Simelton, E., E. D. G. Fraser, Termansen, T. G. Benton, S. N. Gosling, A. South, dan P. Forster. 2012. The Socioeconomics of Food Crop Production and Climate Change Vulnerability: A Global Scale Quantitative Analysis of How Grain Crops are Sensitive to Drought. Food Security 4(2): 163-179.

Saputra, B., R. Linda, dan I. Loviadi. 2015. Jamur Mikoriza Vesikular Arbuskular (MVA) pada Tiga Jenis Tanah Rhizosfer Tanaman Pisang Nipah (Musa ParadisiacalL.Var.Nipah) di Kabupaten Pontianak. Jurnal Protobiont 4(1): 160169.

Tjiptono. 2008. Pemasaran Startegi. ANDI. Jokjakarta.

Untari, D. T. 2016. The Potential Development of Betawi Culinary as an Ecotourism Product in Jakarta. Binus Business Review 7(3): 277-282.

Untari, D. T. dan B. Satria. 2014. Strategi Pemasaran "Laksa Tangerang" Sebagai Salah Satu Produk Wisata Kuliner di Tangerang. Jurnal Manajemen 10(2): 4964.

Untari, D. T., R. Avenzora, D. Darusman, dan J. Prihatno. 2017a. Betawi Culinary; Sosio-Cultures Frame Of Multi Communities In Jakarta. Advance Science Letters 23(9): 8519-8523.

Untari, D. T., R. Avenzora, D. Darusman, J. Prihatno, dan H. Aries. 2017b. Betawi Traditional Cuisines; Reflection the Native Culture of Jakarta (Formerly Known as Batavia). Journal of Economic Development, Environment and People 6(4): 63-76. 